\title{
Measuring Use of a Distance Library Service
}

\author{
by
}

\section{Jacinta Anne Beckwith}

Submitted to the School of Information Management,

Victoria University of Wellington

in partial fulfilment of the requirements for the degree of Master of Information Studies

\section{February 2014}




\title{
VICTORIA UNIVERSITY OF WELLINGTON \\ School of Information Management
}

\author{
Master of Information Studies
}

IMPORTANT DISCLAIMER

with respect to a MIS Research Project (INFO 580)

Measuring Use of a Distance Library Service

(hereafter referred to as 'The MIS Research Project')

being undertaken by

\section{Jacinta Anne Beckwith}

in partial fulfilment of the requirements of the degree of Master of Information Studies, School of Information Management, Victoria University of Wellington.

\section{Topic Commencement: $\quad$ March 2013}

1. Victoria University of Wellington and its Council, its members, staff, employees, students and agents undertake no duty of care in contract, tort, or otherwise, to users (whether direct or indirect) of the MIS Research Project and make no warranties or representations of any kind whatsoever in relation to any of its contents.

2. The MIS Research Project is only made available on the basis that all users of it, whether direct or indirect, must take appropriate legal or other expert advice in relation to their own circumstances and must rely solely on their own judgement and such legal or other expert advice.

3. Under no circumstances will Victoria University of Wellington and its Council, its members, staff, employees, students or agents be liable in any way whatsoever, whether in contract, tort (including negligence), for breach of any statutory or regulatory duty (to the fullest extent permissible by law), or otherwise, to any user (whether direct or indirect) of the MIS Research Project for any loss or damage whatsoever arising directly or indirectly as a result of the use in any way of the MIS Research Project.

4. Each exclusion in the clauses of this disclaimer and each protection given by it is to be construed as a separate exclusion applying and surviving even if for any reason any of the exclusions or protections are held inapplicable in any circumstance. 


\section{Table of Contents}

$\begin{array}{ll}\text { Abstract } & 3\end{array}$

Acknowledgements 4

List of Figures \& Tables

1. Introduction 6

2. Problem Statement $\quad 7$

$\begin{array}{lll}2.1 & \text { Research Objectives } & 7\end{array}$

$\begin{array}{lll}2.2 & \text { Research Questions } & 7\end{array}$

2.3 Rationale for Study 8

2.4 Definitions 9

2.5 Limitations 10

3. Literature Review 10

4. Situational Assessment 15

4.1 Case Study: University of Otago Library 18

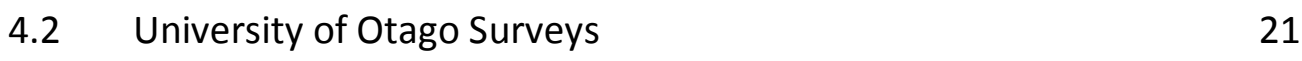

4.3 Statistical Analysis $\quad 22$

5. Research Design 23

$\begin{array}{lll}5.1 & \text { Research Sample } & 24\end{array}$

5.2 Method of Data Analysis 25

5.3 Critical Assumptions 26

6. Findings 26

6.1 Requests made to the Distance Library Service 26

6.2 Characteristics of Users: Institution 30

6.3 Characteristics of Users: Qualification 31

6.4 Characteristics of Users: Field of Study 34

6.5 Discussion 38

7. Recommendations 40

8. Conclusion 41

9. References 43

Appendices $\quad 51$

Appendix 1: Further Tables $\quad 51$

Appendix 2: Participant Information Sheet 56

Appendix 3: Participant Consent Form $\quad 59$

Appendix 4: Interview Schedule $\quad 61$ 


\section{Abstract}

As libraries strive and stride with new electronic resources and online services, providing at point of need and demonstrating value, it is necessary to build more comprehensive understanding of how changes might be impacting use of services and explore what this can tell us about library users.

This research investigates use of a distance library service using the University of Otago Library in Dunedin, New Zealand as a case study. It examines the hard evidence of use of the service represented by requests received and processed by the Distance Library staff between 2007 and 2012. The analysis is made in light of growth in distance learning, advancing information and communications technology and escalation of resources being made available online. The study employs a retrospective quantitative approach and incorporates an analysis of qualification type, field of study and institution of requesters to provide a richer picture for the investigation.

Results of the study provide information about the use of the Distance Library Service and its users revealing trends over time. Research implications of this investigation include better understanding of our information services and our users. Lessons learned from this study can help inform decision-making for future services, training of staff and comparison with other libraries.

Keywords: distance learning, library services, New Zealand, University of Otago 


\section{Acknowledgements}

Thanks to my supervisor Professor Anne Goulding, for your support for my project, for your patience, invaluable feedback and prompt response.

Thanks to Chris King at the School of Information Management for your helpful and timely administrative support.

Thanks to the University of Otago Library for financially supporting my study and for allowing me to undertake this research.

Thanks to University of Otago Library Distance staff, past and present, for participating in the discussion of my research.

Special thanks to Jacinda Boivin for your useful suggestions and support, also to Jeanette Wikaira-Murray and Simon Hart for your advice and encouragement.

To my friends and colleagues at the University of Otago Central Library and Hocken Collections, especially Christy Paterson, Donna Waitere, Emma O'Brien, Mel Lewis and Judith Holloway, thank you for cheering me on, for study dates, after hours work space and for taking care of me during a tough time, all very much appreciated.

To my family, especially my grandparents Anne and Gerald Beckwith, and my Mum Jane, you are my champions and my inspiration, thank you for your unfailing support and faith in me to get this done.

Ngā mihi mahana ki a koutou katoa.

Jacinta Beckwith

February 2014 


\section{List of Figures \& Tables}

Figure 1. Requests Placed by Users to the Distance Library Service 28

Figure 2. Users of the Distance Library Service by Institution 30

Figures 3 \& 4. Comparison of Users by Institution 31

Figure 5. Qualifications Sought by Requesters 32

Figures $6 \&$ 7. Comparison of Qualifications Sought by Requesters 33

Figures 8 -13. Comparison of Requests Received Per Top Five Fields of Study 36

Table 1. Requests Placed by Users to the Distance Library Service 28

Table 2. Recording of Administrative Requests 29

Table 3. Users of the Distance Library Service by Institution 30

Table 4. Qualifications Sought by Requesters 32

Table 5. Top Five Fields of Study 35

Table 6. Categories Used for Coding 51

Table 7. Requests Per Fields of Study 52 


\section{Introduction}

This research investigates use of a distance library service using the University of Otago Library in Dunedin, New Zealand as a case study. It examines evidence of use of the service represented by requests received and processed by the University of Otago Distance Library Service staff over a six year period from 2007 to 2012. The analysis is made in light of the growing popularity of distance education, rapid advances in information and communications technology, escalation of online resources and increasing encouragement towards self-directed study. The analysis aims to offer a representative glimpse into the current status of information services while highlighting key issues surrounding delivery of library services to users at a distance. In particular, the impact of technology on the library's ability to service distance users will be explored.

This study offers a southern New Zealand tertiary perspective but incorporates reflection on distance learning nation-wide and from international literature. From this research we can gain valuable evidence and insight for improvement of services and future planning. Research implications of this investigation include enhanced understanding of our clients and their evolving needs as well as of our own information services. Lessons learned from this study could help inform decisionmaking for future services, training of staff and benchmarking with other libraries. Growth in technological change and innovation is rapidly increasing, while new products and services are always on the horizon. All libraries face escalating quantities of data to manage as well as high expectations for delivery of content and associated tools to maximise users' time and success. That said, Wooliscroft's description (1996, p.1) of the underlying purpose of a distance library service as the provision of quality services of relevant information in a timely fashion is still pertinent almost two decades later. Advances in technology and the internet have only given distance education more credibility as an innovative, legitimate and modern way to learn (Cleveland-Innes \& Sangra, 2010, p.236).

Expansion of online learning and resources has prompted librarians to accommodate fewer materials in the physical building and provide more access to digital resources 
(Bower \& Mee, 2010). Distance library services have evolved from being primarily concerned with posting books out to distance students to helping develop students into successful researchers (White, 2011). As library collections and services evolve, so does our ability to more robustly serve our clients. This is an important and exciting time for libraries: as more resources are made accessible online we must redefine our image and promote our services to demonstrate our value and ability to remain relevant. In order to achieve this we must understand who our users are and what they want. Librarians who are familiar with resources and services their users want and need can make better decisions as to what is bought and shared (Graham, 2009, p. 45).

\section{Problem Statement}

The purpose of this study is to examine and review the use of a Distance Library Service, assess strengths and weaknesses of its use, and identify areas to improve on and develop. The research looks at types of requests made to the Distance Library Services staff as well as characteristics of users of the service to see if these have changed over time. By analysing these features the study hopes to offer a better understanding of the service and its users that can contribute to future planning and directives of the library.

\subsection{Research Objectives}

To identify changes in use of the service over time and propose possible causes of change.

$>$ To build knowledge of our users and our information services that can contribute to future planning and improvement of services.

$>$ To highlight the service, explore the data being captured by the staff and assess whether this can be improved.

\subsection{Research Questions}

1. How is the University of Otago Distance Library Service being used by its users?

$$
\text { Who are our requesters? What services are they using? }
$$

2. How has use of the Distance Library Service changed over time? 
Have methods of recording changed? Have request types changed? Have characteristics of requesters changed?

3. What can the data tell us to help improve library services?

How can we improve our recordkeeping? How else can we improve our services?

\subsection{Rationale for Study}

While much research has been done in user feedback, satisfaction surveys and exploration of challenges faced by those studying at a distance, there has been little investigation published on hard evidence of use of a library service by distance learners. What users think about a service is important, but so is evidence for use of a service. Statistical data provides evidence for quantity of use and can offer significant contribution to development and improvement of services for distance learners. Demonstrating use of library resources is advantageous and can be especially helpful when attempting to show or detect patterns over time (Holloway, 2008, p.491). Information gathered showing the effectiveness of a service can also serve as a powerful tool for arguing for support for the service.

Library services play an integral role in the university learning environment. The longtime challenge of librarians is to know our users and find ways to best serve them so they can achieve academic success. Without a valid, reliable way to collect meaningful data from library activities it is difficult to quantitatively assert how a library adds value (Cox \& Jantti, 2012). Traditionally, value in libraries has been described in terms of resources available, however this does not always suffice when it comes to distance learners who may not be aware of resources available to them or know how to effectively use those resources (Holloway, 2008, p.489). Collection and assessment of data about an organisation's activities has the potential to improve effectiveness and efficiency of those activities.

Measuring a library's output offers opportunity for evaluation of library performance. These measures can identify the success in which services are provided and used and can contribute to a better understanding for decision-making groups who allocate resources (Hafner, 1998, p.69). Measurement and evaluation can also help identify areas for improvement. In this study, output measures used for analysis are the 
services and resources rendered by the distance library service to distance requesters. Circulation statistics and database access statistics are unlikely to distinguish distance learners from the wider student population, so analysing the evidence of transactions between distance library staff and distance learners over a six year period offers the opportunity to make a valid contribution towards a better understanding of this service. Using this sample is an effective way to learn more about library services and distance learners at Otago.

\subsection{Definitions}

"Distance Education" or "Distance Learning" can best be described as learning that takes place when a student is not in the physical location of the instructor or classroom (Nickel \& Mulvihill, 2010, p.88). Distance learning is described on the University of Otago website as planned learning normally occurring in a different place or time from teaching, requiring special course design and instruction techniques and use of technologies to enable communication, access to resources and student support (University of Otago, 2014c). Distance learning involves self-directed study using course materials provided in hardcopy, online, CD-Rom or DVD while interaction with lecturers and other students might be by audio conference, web conference or online discussion forums (University of Otago, 2014a).

"Distance learners" refers to any student enrolled in a University of Otago or Otago Polytechnic Distance course or paper. It also refers to those living outside Dunedin, whether in New Zealand or abroad, including dissertation students and students on placement. Students registered with Disability Information \& Support are eligible to use the Distance Library Service. Staff involved in Distance Learning are also able to use to service.

The terms "users" and "requesters" refers to clients of the library, those registered with the Distance Library Service and using services and resources provided by the library.

"Requests" refers to requests for information and support from the Distance Library Service including: books posted, journal articles and book chapters scanned and emailed, research support, advice and help accessing library resources including e- 
journals, e-books, article databases and any other electronic resources. Requests for services are usually received electronically via an online request form or email, but also via telephone, in person and occasionally by post.

\subsection{Limitations}

All efforts have been made to ensure the integrity of this research; however the researcher acknowledges the following potential limitations:

1. Data analysed is limited to request information received by library users registered with the University of Otago Distance Library Service; effectively only those studying at the University of Otago or Otago Polytechnic who are aware of, eligible for and actively using the Distance Library Service. This cohort of students is only part of the distance learning community at Otago, and a small group within all distance learners in New Zealand.

2. Data analysed has been drawn from a database maintained by various distance library staff over a six year period from 2007-2012. The study relied on accurate input of details by requesters (via the online request form) and by all distance library staff using the database over this time.

3. Research is based on data from one group of library services at one university in southern New Zealand and may not be applicable or comparable to all tertiary institutions.

\section{Literature Review}

Library services for distance learners is a prominent topic among academic libraries and existing literature on distance learning and library use is varied and extensive. Earlier literature on distance library use has focused on surveys, satisfaction studies and focus groups (Kelley \& Orr, 2003; Moyo \& Cahoy, 2003). Newer literature discusses changing patterns of library use driven by technology (Agorogianni, Zaharis, Anastasiadou \& Goudos, 2011; Olivas \& Chan, 2013; Primus 2009). Many institutions have undertaken surveys involving their distance clients with the motive of improving services and to better contribute to retention and success of their students. Some have surveyed distance librarians about services and resources offered (Cassner \& Adams, 2004; Fritts, 2010), others survey distance learners about library services (Alewine, 
2012; Ashby 2011; Pitts, Coleman \& Bonella, 2013) and recent research looks at the direct correlation between library resource usage and student performance (Cox \& Jantti, 2012; Stone, Ramsden \& Pattern, 2012). Growth of distance education around the world has brought a growth in writing about its effects on practice and experiences of both learners and teachers, and there is now a range of journals linked to distance, open and flexible education (for example, Distance Education, Distance Learning, Journal of Open, Flexible and Distance Learning, Journal of Library \& Information Services in Distance Learning).

In an analysis of distance library use literature between 1999 and 2009, Herring showed that access to services and resources was a particularly pertinent topic and articles grappling with changes caused by new technology rose over this time (Herring, 2010, p.141). The results of Herring's analysis reveal both an increase in and increasingly diverse approach to the study of library services for distance education. Expanding this research base through valid research, measurement and evaluation methods is important for enabling librarians serving distance users to improve knowledge and enhance ability to improve services for example, Nichols (2006) suggested use of a monthly survey and monitoring of library services for distance learners could be valuable. With both qualitative and quantitative data gathered in a survey administered to students on a monthly basis, a quick response to concerns could be achievable whereby action would be taken in a timely fashion to make changes of benefit to distance students.

Research by Tripathi and Jeevan (2009) looked at how distance learning libraries could improve upon existing services to enhance quality of service for distance learners. Comparison of library practices is made between three open universities in Hong Kong, United Kingdom and Canada. Results reveal all three universities offer comprehensive library and information services for distance learners. An action plan is proposed for distance learning libraries with suggestions for improving library service. The study makes the important point that simply providing access to education is not enough, support for learning success also must be provided. With effective support services, students are more likely to succeed and experience a better quality of learning. 
Communicating resources and services to users through library web pages and marketing essential services is considered vital for success.

Internationally, academic libraries have been investigating links between student library use and engagement with academic success, testing the hypothesis of a correlation between library activity and student attainment (Stone, Ramsden \& Pattern, 2011). The library, both as a traditional repository for publications and as a gateway to electronic resources, plays a critical role in any tertiary institution. Today, libraries are experiencing competing priorities, limited resources and exponential growth in information technology. Libraries are expected to demonstrate themselves in terms of value provided to users in ways that can be described and measured, to justify funding, resources and very existence. The Library is an essential source of information, services and expertise for enhancing academic endeavours and it provides an important and valuable array of services in support of scholarship, creativity and learning for its community both on-campus and off. The distance library service makes its contribution to the university by providing high quality services to distance learning students and staff. Library and information support is considered an essential component in providing distance learners with a quality educational experience (Needham \& Johnson, 2007, p.118).

Surveys of distance learners and of distance librarians represent a popular research method employed to gather information and many of these studies have revealed a lack of awareness of services and under-utilization of libraries by distance learners. Many surveys have been undertaken by institutions to help improve services, better tailor services to clients, for retention and success rates. In a very recent study at Kansas State University, librarians surveyed their distance education community to determine what services, resources, and promotional efforts were most needed to be of greatest service in response to fulfilling the University's mission (Pitts, Coleman \& Bonella, 2013). The research documented a lack of awareness and consequently lack of usage of library resources within their distance community. A key takeaway of this study is that what we develop and market to our distance community will be of benefit to all library users as access and services increasingly move to digital formats. 
Research by Selwyn (2011) suggests that use and non-use of technologies by distance learners is a complex issue, guided by how each individual perceives the fit between technology, education and the wider circumstances of their lives. Technology is a major component of library work and librarians' roles are changing in response to evolving technological applications. The capacity to deliver library services to distance learners is enhanced by the potential of technology, but distance learners must also be able to use the technology and be aware of those services.

While reviewing the literature it is important to acknowledge two important studies which relate directly to the University of Otago Distance Library Service. Vare (2002) created a template of twelve essential services as a benchmark for measuring library service provision for distance students. Guidelines are considered important as they assert the rights of distance learners to equivalent levels of support for on-campus learners (Needham \& Johnson, 2007, p.119). Responses to Vare's survey indicated the majority of New Zealand libraries serving distance students provided most essential services listed but there was substantial difference in levels of services offered with some institutions providing no library services for off-campus students. Vare emphasised proactivity in ensuring provision of high quality library services and expressed the need for evaluating services offered from all perspectives and the publishing of these results. Keeping a variety of detailed statistics helps provide evidence of what the service is doing and provides information for funding, planning and development of the service which can be presented to library management, faculty and distance educators.

Fisher (2005) studied computer literacy of distance students at the University of Otago to examine how they coped with using information technology from a distance. Fisher's investigation looks at policies and literature regarding distance students at New Zealand universities and the Open Polytechnic, and research was undertaken with distance students at the University of Otago. Use of support services provided by the institution was queried as well as students' coping strategies. Results of the survey showed a significant number of students struggling with technology with Blackboard (the online learning environment for course material), class discussions, assignments and assessments causing the most frustration, followed by access to library resources. 
Many distance learners used local resources for information rather than their institution. The study noted that students often make do with what they can access easily, rather than persevere with electronic resources requiring more time and commitment. Technology usability is important for all library users, but particularly so for distance learners as difficulty connecting to online library resources is equivalent to the library being closed.

In another New Zealand study, Lee (2008) investigated types of reference services offered to distance students at the University of Canterbury. This research aimed to investigate users' knowledge and satisfaction with distance services as well as the kinds of barriers preventing distance students from using these services. A comparative study was made of the attitudes distance students have towards three reference services: phone, email and chat. Due to the small response rate Lee was reluctant to make definitive conclusions from the results; nonetheless it makes a valid contribution towards knowledge about library service for distance users and inspiration for future research. Results indicated that most distance students were satisfied with the service they were receiving from each of these reference services with email reference being the most popular while also revealing distance users' knowledge of reference services as surprisingly low. Lee offers a number of sensible suggestions for improving the service including promotion and implementation of methods to make the service more user-friendly, efficient and effective (Lee, 2008, p.73).

While student engagement is now seen as vital to quality tertiary education, information about student engagement has not been readily available to Australasian tertiary education providers until recently. The Australasian Survey of Student Engagement (AUSSE) is now an annual survey managed by the Australian Council for Educational Research (ACER) in cooperation with participating tertiary education providers in Australia and New Zealand (Radloff \& Coates, 2011, p.vi). Prior to 2007, existing data collections and surveys tended to focus on student satisfaction, quality of teaching and other aspects of students' experience at their institution. Since then, the AUSSE has been implemented at many institutions, offering increased opportunity to understand student engagement and what matters for their experience, including 
those learning at a distance (Radloff, 2011, p.vii). The AUSSE report explores student engagement among students at New Zealand's universities, and focuses on student groups of particular interest to the New Zealand higher-education sector, including Māori and Pasifika students, international students and students studying via part-time or distance. It highlights the ways in which these students learn and the outcomes which they achieve. By providing access to information resources, academic libraries play a significant role in the student experience and this success.

Despite proliferation of literature on library services and distance learning there is yet a lack of institutional research specifically regarding hard evidence of use of a service. Focus lies with practice and policy, user surveys and satisfaction surveys, all of which could be enriched with hard data. Particularly over the last decade there has been increasing interest in exploring information access and use by distance learners. Usage data form an important part in telling the story of the impact of library resources on student experience and can be used hand in hand with surveys, analytics, market research and student feedback. This information not only helps us understand where and how library resources are having impact but it also has a role to play in moving our services forward.

\section{Situational Assessment}

University libraries around the world have for many years been searching for ways to measure and demonstrate the value and impact of their services to students, both in terms of satisfaction and, more importantly, their contribution to academic success. The hypothesis has always been that library use is an indicator of positive engagement with studies and that exploitation of the rich resources and support provided by the library will enhance the quality of assessed work (Oakleaf, 2010). The steadily developing availability of online library services over the past decade has revolutionised library use worldwide and its impact on distance study has also been profound. In the past, a distance student would need to allow two to three weeks for a response to a written or emailed request for journal articles from the Library (Prebble, 2010, p.46). Today, students can access the Library's online catalogue from home, 
search a range of online journals at leisure and copy and print any articles that look useful, within copyright.

Many distance students never enter the physical library so serving a distance population encourages creativity in marketing methods. Distance students may have limited expectations and knowledge of library services available to them so it is important to make sure that students are aware of and have the capability to access and effectively use resources. Ensuring provision of appropriate outreach and services to these students makes the library relevant to the University (Holloway, 2011). Our ability to make resources available in an electronic environment demonstrates to students the immediate value of the library. Our challenge is to ensure that instruction in information literacy and research is offered so that distance students can effectively advance in their scholarship while learning to do research on their own, a patronempowerment. It is through students' recognition of the value of research sources and the use of research tools that the academic library will maintain its relevance to the student population regardless of distance.

The Tertiary Education Strategy 2010-15 sets out the New Zealand Government's expectations and priorities for New Zealand's tertiary education system, highlighting student engagement and success as of strategic importance (Ministry of Education, 2010b). A key objective for universities is improving course and qualification completion rates. Suggestions for achieving this include:

Helping people achieve highest potential

Improving relevancy, efficiency and doing better with what we have

Supporting and encouraging student performance

All of these goals are also highly relevant to library services.

The Government has signalled an intention to fund tertiary education on the basis of completion and pass rates rather than enrolment rates and this has strong consequences for distance providers since completion rates for distance students are often lower than for on-campus students in the same course or qualification (Anderson, 2010, p.4). For those studying at a distance and physically separated from teaching staff and other learners, study can be challenging and success elusive. 
Distance students often report feelings of isolation, little sense of connection and belonging, and difficulty maintaining engagement in and motivation for learning (Grant, Olivier, Rawlings \& Ross, 2011, p.159). This should provide an incentive for tertiary libraries to provide appropriate learning support that can give a positive and lasting effect towards student success.

Distance learning has grown to be a major component in New Zealand education, with all eight universities in New Zealand now offering some form of flexible or distance programme. It was first offered through the Correspondence School in the 1920s (Vare, 2002) and in the past, distance learning took place via postal correspondence. Today's distance learners are more likely to employ the internet and its various communication methods such as email, streaming video, instant messaging, in combination with an online learning management system. New Zealand distance and campus-based students are quite different in terms of their demographics. Distance students are more likely to be older, female, studying part-time and are more likely to be combining work with study, seeking to improve qualifications, knowledge and skills (Poskitt, Rees \& Suddaby, 2011, p.76). In 2010 the proportion of New Zealand distance students was calculated at around $17 \%$ of all learners (Ministry of Education, 2010a). While web-based technology has impacted distance learning it has also had effect on the nature and delivery of support services provided to students. One of the most important and impacted areas of student support is library service (Cooke, 2005, p.51). Over the last decade, there have been numerous advances in the library world, for example, libraries subscribe to online databases that provide unprecedented access to periodicals and provide access to electronic books, library staff create websites, virtual tours and respond to reference questions via email and instant messaging. Libraries offer accessibility through various forms of social media such as blogs and Twitter, with supplementary online reference support and research tools such as LibGuides and online tutorials (Massis, 2013, p.269). Web technology has redefined ways in which libraries provide resources and services to the benefit of all learners.

As an important academic unit, the library assists with knowledge development and is critical to a university's teaching and learning process. Library technology impacts the daily operations of the university, including faculty and student access to online 
resources, collaborations with other libraries and institutions, digitization, book ordering and the ability to do appropriate research. The role of the library is progressive, competitive and has been referred to as part of the basic foundation for building a knowledge economy (Mohssin \& AL-Ahmad, 2005).

As universities, and consequently university libraries, are under increasing financial pressures there is subsequent requirement to measure activity levels and demonstrate value for money (Needham \& Johnson, 2007, p.125). Library work can easily be preoccupied with responding to day-to-day operational demands, making it difficult to step outside the moment and reflect on the impact of what we are doing yet it has never been more important to demonstrate our value and significance. Libraries must prove themselves in terms of value provided to users in ways that can be described and measured (Kyrillidou, 2002, p.43). For New Zealand, financial pressure has been reinforced with the introduction of a performance-based funding element that uses learner retention and completion as key indicators of university success (Shillington et. al., 2012, p.65). In this environment student support services are increasingly important, particularly the ability to deliver targeted, cost-effective and equitable services and to provide evidence of their relevancy and success.

\subsection{Case study: University of Otago Library}

The University of Otago is New Zealand's oldest university, founded in 1869 , and has achieved international reputation for excellence in both teaching and research (Hayne, 2013, p.1). Since 1985, the University has delivered a range of distance courses across the Humanities, Business, Science and Health Science areas. In 2013 more than 120 distance programmes were offered with specialist programmes indicative of Otago's particular strengths in medicine and related health sciences but otherwise encompassing a diverse range of subjects (Anderson, 2013, p.1). Otago demonstrates a particular commitment to supporting distance learning in fields where the University has specialist knowledge and expertise, such as Postgraduate Health Sciences. Distance learning contributes significantly to the financial well-being of the university and plays a lead in the use of learning technologies including audio-conferencing, videoconferencing, podcasting, blogging and computer mediated communication, including Blackboard. 
Otago is a research-intensive and predominantly campus-based university with focus on high quality research, teaching and services (University of Otago, 2013d, p.1). By its mission, the University of Otago fosters core values that include equity in educational opportunities and support for full and equal participation and outcomes. The University of Otago Library follows the major strategic initiatives of the University, in particular:

1. to create, advance, preserve, promote and apply knowledge, critical thinking and intellectual independence to enhance the understanding, development and well-being of individuals, society and the environment

2. to foster high-quality, research-active staff their development in a supportive environment

3. to provide a similarly attractive, supportive environment for research students Students enrolled in distance courses can expect access to up-to-date knowledge delivered through sophisticated learning technologies. The University upholds that students at a distance have full and equal rights to access the resources held in the various libraries located on campus. Even if all users are given equitable access to library resources and services using equivalent technology, their ability to capitalize on the resources would still be influenced by their skills and experience in using libraries and information resources, which is where library staff come in.

The University of Otago Library provides services and resources to a population of undergraduate and postgraduate students as well as university faculty involved in various fields of study across the Humanities, Commerce, Sciences and Health Sciences. Library collections comprise an immense variety of publications, books, print journals, electronic books, online journals and an array of electronic resources. As a reflection of the change in preference from print to online resources, between 2007 and 2012 the Library's print serials decreased by $26 \%$ and electronic serials dramatically increased by $221 \%$ (University of Otago, 2013c).

The University of Otago Distance Library Service provides assistance to students enrolled in a distance paper or course whether physically located in Dunedin or geographically distant, dissertation students no longer physically present on-campus, mixed enrolment students who may at times be physically present on-campus. 
Students registered through the Disabilities Office are also eligible to use the service as are university faculty teaching distance courses or undertaking research abroad.

Students who are enrolled in an on-campus paper but go out of Dunedin on placement can also use the service.

The University of Otago Library provides the following services to users of the distance library:

$>$ Free postal delivery and return of books

Electronic delivery of chapters and journal articles from the library's physical collections

$>$ Remote access to library databases

Remote access to online course reserve readings

$>$ Free interlibrary loan within Australia and New Zealand with electronic delivery where possible

$>$ Nation-wide toll-free telephone number and email for requesting services

$>$ Reciprocal borrowing privileges at other Australian and New Zealand university libraries

Information literacy instruction including help navigating online resources and services

Direct benefits for using library services are focused on cost and time saved for the user. These benefits include cost savings from avoiding purchase of materials as well as access to trained professionals for assistance in finding quality information. The Library has a responsibility to ensure students are aware of all services available to them and should use as many different ways as possible to promote the full range of assistance the library can offer during their studies. Reaching distance users and making them aware of services available can be achieved through various means:

Posting out promotional material with course packs

Visiting in person

Using social media - institutional websites, facebook, blogs, video tutorials

Closer liaison between teaching and library staff 
The University of Otago Library seeks to accomplish all of these methods of outreach. Information about the Distance Library Service is included in Distance Learning Support packs. Senior library staff undertake visits to learners, although less regularly than in the past and the visits are no longer recorded in the database. The Distance Library Service has an online LibGuide with video tutorials. There is still room for improvement with exploring other social media and relationship-building with faculty.

\subsection{University of Otago Surveys}

Two surveys, one annual and one biannual, already gather information from University of Otago students regarding their use of and satisfaction with library resources. A survey conducted biannually by the University of Otago Distance Learning Office investigates student access to technology, and access and utilisation of various online support services provided by the university including awareness and use of services and research tools available from the library (Anderson, 2012, p.4). Results from their 2012 survey indicate students are for the most part satisfied with distance services provided by the Library, but suggest more promotion of the services is needed to reach more users. Libraries can never take for granted knowledge about our services, and as there are new intakes of students every year, promotion of services and resources can never cease. Distance learning institutions and libraries have a responsibility to promote our services and resources to distance students even if this causes increasing demand, and even if students do not use the distance library service within their first year, knowledge of the types of services could help them in the future.

Prior to this survey, little was known about the extent to which Otago distance students accessed support material online (Distance Learning Office, 2008, p.10). These results can now serve as an initial benchmark against which further monitoring of student access to support services might be considered. Most distance students have little opportunity to engage in support activities on-campus so the provision of interactive online support is an important step forward in support for distance students. Results of the 2008 survey showed that almost half of all distance students requested support in their study, most often from the library (Distance Learning Office, 2008, p.13). 
The Student Opinion Survey has been conducted annually by the University of Otago Quality Advancement Unit since 1995 (Mirosa, 2011). This survey gains student feedback on the university environment, computer access, space, staff and access to resources including libraries. It marks the University's rolling programme of evaluation of the educational experiences of its students and graduates. Questionnaires are sent to randomly selected students, and from 2006 the Survey was made available online with print versions available upon request. From 2007 the Survey was split into two parts: academic experience and support services, to reduce the length of the questionnaire and improve response rate. In the Support Services Survey, students are asked to rate their level of satisfaction with a wide range of University support services including services provided by the library.

\subsection{Statistical Analysis}

Statistics provide evidence of changes in our environment which can contribute to knowledge and understanding of our business. On the positive side they give us the ability to track patterns over time and compare with other institutions. On the negative, they require a certain amount of staff time and effort for maintenance, particularly when it comes to making sense of the data, but if we do not use the data then why keep it?

Whitehead (2007) gives a particularly useful overview of why gathering library statistics can be both useful and unhelpful:

Why statistics are useful:

Enhances understanding of users and their demands

$>$ Contributes to understanding and improvement of service delivery

$>$ Demonstrates extent and nature of complex changes over time

Provides evidence for reasoning, resource allocation and budgeting

Determines how well we are going in relation to like institutions and to ourselves, over time

Why statistics may be helpful:

Can be time-consuming 
$>$ Can contain inaccuracies and end up meaningless or misleading

Some user or opinion data can be unreliable

Consistency can be hard to achieve

Comparisons are not always straightforward between complex service environments

Whitehead (2007) also emphasises what library statistics should do, which is to:

$>$ Give an idea of actual outputs

$>$ Indicate changes in type or balance of outputs

$>$ Relate what we do to what others do

Understand the user better

Help to plan

$>$ Change and be relevant but remain consistent

This research looks at the statistical data in the form of requests made to the Distance Library Services staff. It also looks at characteristics of users of the service. By analysing these features the study hopes to offer a better understanding of the service and its users that can contribute to a more complete picture of trends which may assist in future planning and directives of the library. However, keeping in mind the pros and cons surrounding the use of statistics, it is recognised that the sometimes complex narrative that accompanies a request cannot easily be captured by simple statistics. Problems can also arise with a lack of common definition, standardisation and reliability, all of which have been experienced during the course of this study.

\section{Research Design}

This research explores use of the University of Otago Distance Library Service by examining requests received and processed by the service between 2007 and 2012 . The study attempts to reveal trends in library services and library users over time. Data was initially captured in a Filemaker Pro database either input directly from the online distance request form filled out by the requester, or manually entered by library 
staff. This data was exported into Excel by the researcher for spread sheet analysis and graphing purposes. Specific areas examined are:

Quantity of requests made to the service each year

$>$ Type of requests (what the request is for)

Characteristics of users (institution, qualification level and field of study)

Findings are displayed in tables and graphs. Larger tables are included in the Appendices.

\subsection{Research Sample}

As part of preparation for this project, distance library services at other New Zealand institutions were considered, particularly the leaders in distance education. Massey University offers one of the largest university-level distance education programmes in Australasia with its distance library service recently celebrating fifty years of operation (White, 2011) and the Open Polytechnic of New Zealand has been a specialist national provider of open and distance learning at tertiary level since 1990 (The Open Polytechnic of New Zealand, n.d., as cited in Barrett, 2011, p.10). Victoria, University of Wellington, at which the researcher is currently a distance student, was also considered. This research project emerged from the researcher's personal interest and experience as a distance student while working as part of the University of Otago Distance Library Service. Due to time and data management constraints of the project, only the Otago Distance Library Services were investigated.

The data used in this study is drawn from library users who are aware of services and resources available to them. Even though not all distance learners at Otago are represented in this sample, this is considered acceptable because samples are usually only representative of the population from which they are drawn. The study offers a southern New Zealand tertiary library perspective.

Measures used for analysis are the services and resources rendered by the distance library service to distance requesters. Circulation statistics and database access statistics are unlikely to distinguish distance learners from the wider student population, so analysing the evidence of transactions between distance library staff and distance learners over a six year period offers the opportunity to make a valid 
contribution towards a better understanding of this service. An analysis of qualification type, field of study and institution of requesters can provide a richer picture for the investigation. This data analysis represents a quantitative retrospective study of hard evidence of use of the distance library service.

\subsection{Method of Data Analysis}

The collected data was exported from Filemaker into an Excel spread sheet to allow for better manipulation, analysis and interpretation. Excel-formatted results were analysed according to various criteria, pivot tables were employed and statistics were compiled using percentages and displayed in graphs. The technique used was descriptive and statistical, and tools employed include percentages, tables and graphs to produce a quantitative profile.

As each request made to the distance library service corresponds to a requester, careful consideration was made to exclude personal or identifiable information in the results thus variables in the study are displayed in an aggregated and anonymized form. Variables relating to requesters include qualification type, field of study and home institution. The main variables investigated are request types, whether for a loan, electronic copy or other category such as citation advice or help with accessing online databases, more fully explored below. Analysis of this data will provide evidence for how the library service is being used over time while variables relating to the requesters will help build a bigger picture of who we are providing services and resources for. While the University of Otago Distance Learning Office builds a picture of the whole distance population biannually; this study focuses on those who are using the library services and resources with help from the Distance Library Service.

The researcher filled in gaps where possible. Some gaps in the data were unable to be filled as the corresponding records are no longer available to verify. An unknown entity was recorded as a blank or as cancelled.

The researcher considered looking at regional diversity among requesters, but after a preliminary examination of the data it was decided that those results would not bring adequate benefit to the study. It does not matter where in New Zealand (or overseas) the requester is located, unless we were taking account of postage costs. When 
responding to a requester whether in New Zealand or abroad, the most effective and efficient method to fulfil a request is employed, usually electronically.

Supplementary to the data analysis a series of four brief interviews with University of Otago Library staff who were part of the Distance Library Service between 2007 and 2012 was also undertaken to provide depth to the analysis. Ethical Approval for these interviews was sought and granted by the SIM Human Ethics Committee. The main purpose of the interviews was to discuss initial findings of the analysis and obtain clarification on categorical terms used for recording statistics. A secondary benefit to the interviews was for the researcher to gain further perspective on the Distance Library Service. No specific data from these discussions were used in this research except for the categorical terms and descriptions as found in the Appendices.

\subsection{Critical assumptions}

1. That the requester has input true and correct information

2. That distance library staff have verified those details and kept them up-to-date and orderly

\section{Findings}

\subsection{Requests made to the Distance Library Service}

The collection of Distance Library requests recorded between 2007 and 2012 involved sixteen different categories of request types, whereby variety of use reduced over the years. For the purposes of this research these categories were condensed to five:

1. Copy - article or chapter emailed or posted to user

2. Loan - borrowable item issued and posted to user

3. Help - any kind of relevant help or information provided to user

4. Visit - face-to-face visit with user

5. Cancelled - duplicated or unknown request

"Help" covers a wide variety of transactions and could signify but is not limited to:

Advice given to user on how to pay fines

Borrowable item issued and posted to user 
$>$ Help given with searching library catalogue or databases

Help with accessing items remotely

Help with accessing online resources from Education Resources Information Center

Help with citation or citation style

Help with clearing debt from fines, fees or invoices from 2007 (only used 2008)

Invoice sent to user

New password input into user's account

Query involving complaint, alert of or help with overdue or recalled item(s)

Query passed to IT staff or technical support given

Registration of user with Distance Library Service

Renewal of item(s) on loan to user

Requester directed to online past exam paper(s) or past exam(s) sent to user

Re-sending of requested item to user

Table of contents sent to user

User advised not to send lists of requests on one form

User sent a postgraduate study guide or directed to online guide

User sent Distance Library Request Form in mail or directed to use Online Request Form

A full table of categories with descriptions and category assigned to each is included as an Appendix. 
Table 1. Requests Placed by Users to the Distance Library Service

\begin{tabular}{ccccccc}
\hline Request Type & $\mathbf{2 0 0 7}$ & $\mathbf{2 0 0 8}$ & $\mathbf{2 0 0 9}$ & $\mathbf{2 0 1 0}$ & $\mathbf{2 0 1 1}$ & $\mathbf{2 0 1 2}$ \\
\hline Copy & 5880 & 5762 & 5319 & 5138 & 4671 & 3938 \\
Loan & 3165 & 2666 & 3357 & 3863 & 3483 & 3359 \\
Help & 1420 & 1602 & 1798 & 105 & 9 & 0 \\
Visit & 14 & 7 & 6 & 0 & 0 & 0 \\
Cancelled & 28 & 28 & 32 & 26 & 0 & 0 \\
\hline Total & $\mathbf{1 0 5 0 7}$ & $\mathbf{1 0 0 6 5}$ & $\mathbf{1 0 5 1 2}$ & $\mathbf{9 1 3 2}$ & $\mathbf{8 1 6 3}$ & $\mathbf{7 2 9 7}$ \\
\hline
\end{tabular}

Figure 1. Requests Placed by Users to the Distance Library Service

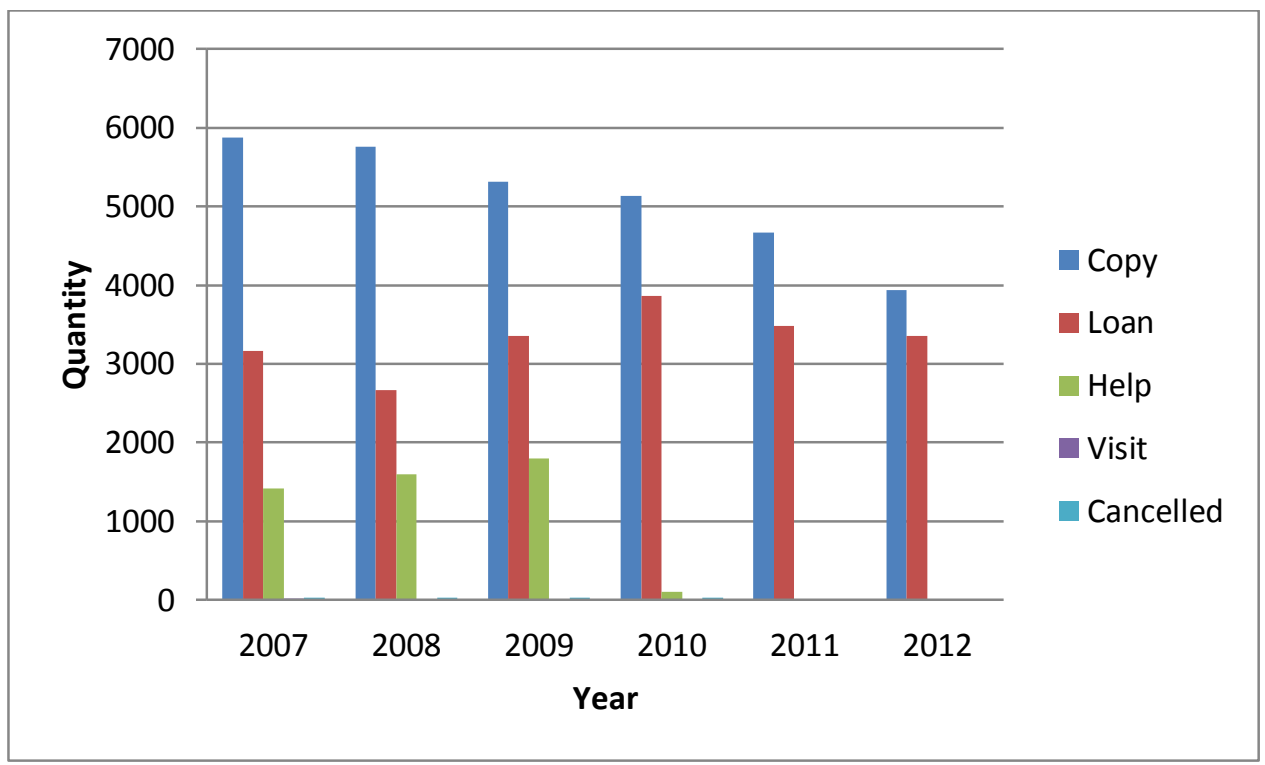

Results show that the quantity of requests recorded has decreased over time, and that the various requests recorded has been reduced to just two by 2012. All requests received by the Distance Library Service are now being recorded as either copy or loan. Copies outnumber loans every year, but have also reduced in number each year. No visits are being recorded, and help has either been absorbed as part of a copy or loan transaction or no longer being recorded. Cancellation of requests is also no longer specifically recorded.

The reduction of requests might seem that the Distance Library Service is being used less; however the researcher knows that help is still being requested even if not recorded. Requests are also sometimes passed on to more senior staff to manage if it involves a more specific enquiry requiring more detailed assistance which means details of the request may be recorded elsewhere by the senior staff. In discussion 
with past distance staff it was clarified that some statistics, particularly more detailed requests, have long been recorded elsewhere. In fact there are several different methods used for recording statistics by library staff and it would require a major enterprise to bring them all together and draw conclusions from them. This could be a possible avenue for future research.

There are further possible reasons for the reduction in requests:

Increase in electronic content available through Library subscriptions

Increase in electronic content available openly via the internet

Students are being supplied with readings by their lecturer via Blackboard

Students are using other sources for reading material

Students are needing less staff intervention

Staff are recording requests differently or elsewhere

Tasks which were recorded in the past are no longer being recorded at all Administrative data such as requests for renewals, aiding with fine payments and dealing with an overdue or overdue recalled item are no longer recorded. The table below demonstrates just how significant these requests were in the past.

Table 2. Recording of Administrative Requests

\begin{tabular}{lcccccc}
\hline Request Type & $\mathbf{2 0 0 7}$ & $\mathbf{2 0 0 8}$ & $\mathbf{2 0 0 9}$ & $\mathbf{2 0 1 0}$ & $\mathbf{2 0 1 1}$ & $\mathbf{2 0 1 2}$ \\
\hline Renewals & 345 & 379 & 696 & 79 & 0 & 0 \\
Overdue/Recalls & 205 & 139 & 123 & 3 & 0 & 0 \\
Fines & 31 & 43 & 40 & 0 & 0 & 0 \\
\hline
\end{tabular}

A further explanation for the reduction in requests over the years could be that tasks such as renewals and fine payments are accepted as part of daily duties taken for granted. Another administrative task, invoicing, which was once recorded albeit not very often is no longer a part of service. 
A simplification of request types makes data recording much easier, but may mean that there is a loss of information. These statistics are fairly basic to begin with so any diminishing of the recording of potential meaningful interaction between staff and user could be disadvantageous for providing evidence of use of a service.

\subsection{Characteristics of Users: Institution}

The Distance Library Service supports students and staff at both the University of Otago and the Otago Polytechnic. Students can access the Distance Library services and resources including the online request form via their respective institutional websites. Requests can also be made by email, by phone, in person or even by postal letter. Students' online access to electronic resources varies between institutions depending on subscriptions owned by each institution, a point often difficult to convey over the phone. The Distance Library Service will supply any resource that a student is unable to access from home or work, and this is treated as either an interloaned item or simply an item that the student could have accessed if they were able to physically be in the library building. Incidentally, the exploration of interlibrary loans and document delivery has not been included in this research.

Table 3. Users of the Distance Library Service by Institution

\begin{tabular}{ccccccc}
\hline Institution & $\mathbf{2 0 0 7}$ & $\mathbf{2 0 0 8}$ & $\mathbf{2 0 0 9}$ & $\mathbf{2 0 1 0}$ & $\mathbf{2 0 1 1}$ & $\mathbf{2 0 1 2}$ \\
\hline Otago Polytechnic & 122 & 127 & 138 & 149 & 200 & 225 \\
University of Otago & $\mathbf{7 3 0}$ & 667 & $\mathbf{7 0 0}$ & 613 & 532 & 597 \\
\hline Total & $\mathbf{8 5 2}$ & $\mathbf{7 9 4}$ & $\mathbf{8 3 8}$ & $\mathbf{7 6 2}$ & $\mathbf{7 3 2}$ & $\mathbf{6 2 2}$ \\
\hline
\end{tabular}

Figure 2. Users of the Distance Library Service by Institution

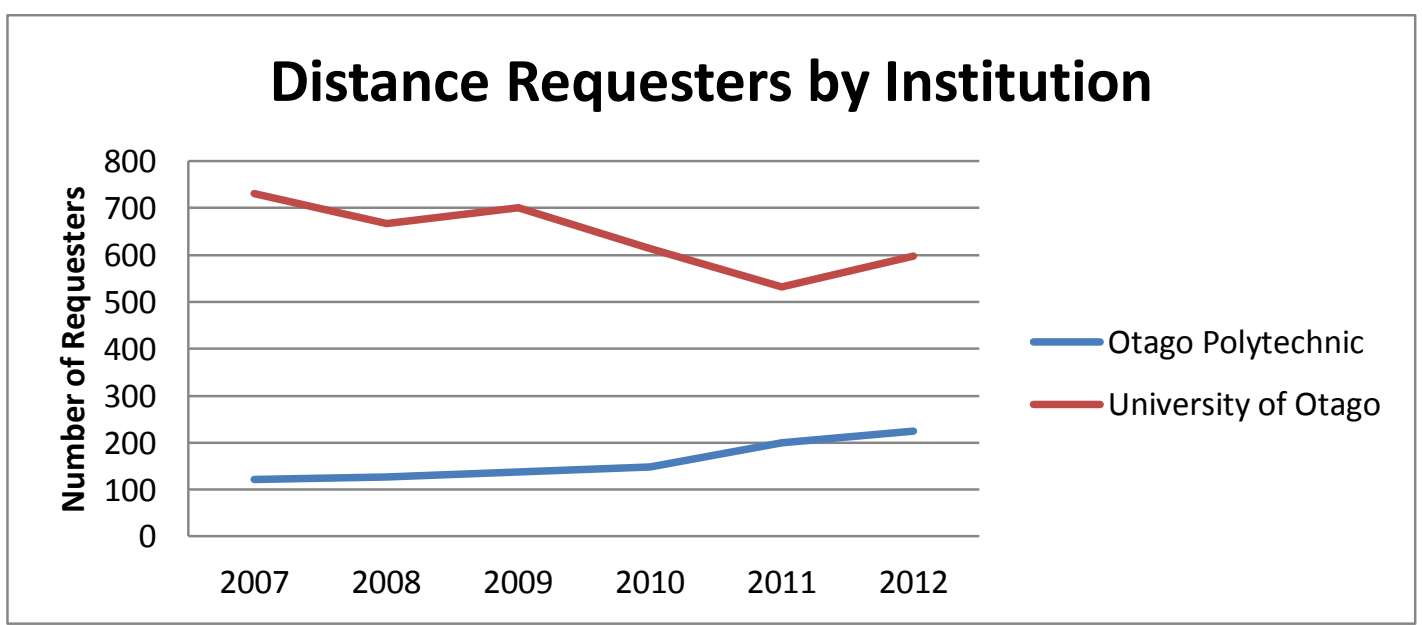


Figures 3 \& 4. Comparison of Users by Institution

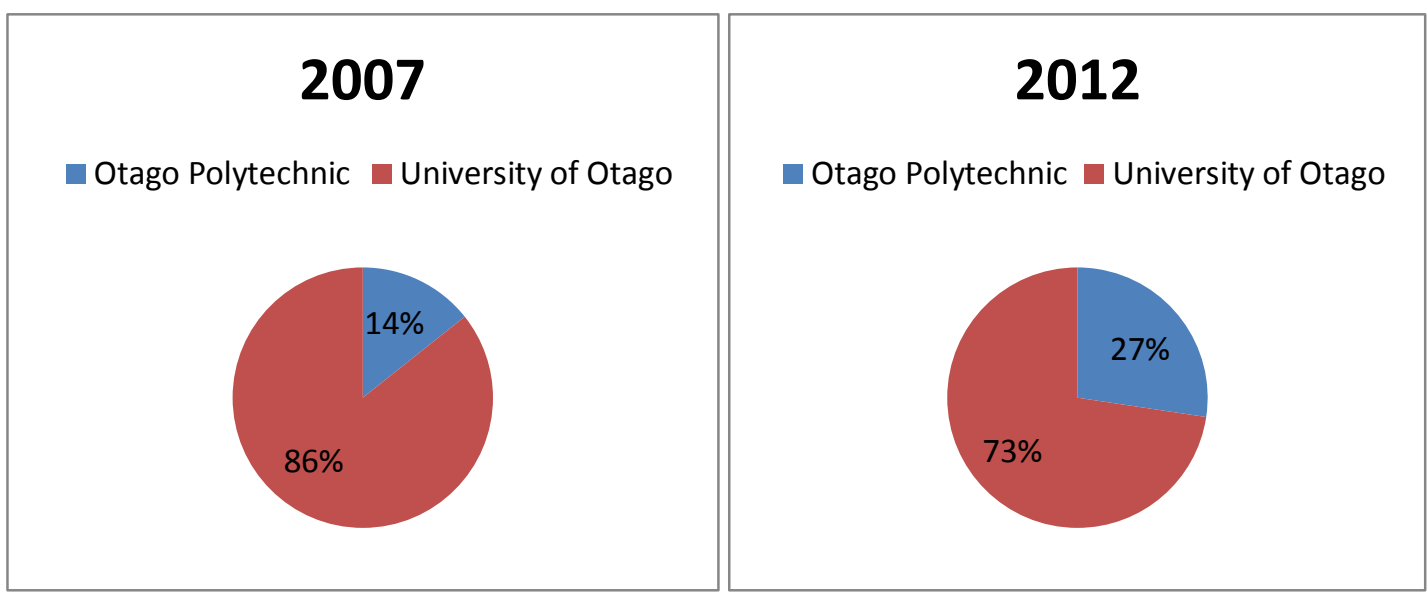

An analysis by institution shows fluctuations in numbers of requesters over the years and the gradual increase of requesters from the Otago Polytechnic. Polytechnic requesters have grown from comprising $14 \%$ of our users to $27 \%$.

\subsection{Characteristics of Users: Qualification}

The biggest users of Distance Library Services have always been recorded as postgraduates and this can be contributed to more distance papers and courses offered at a postgraduate level as well as the likelihood of students on placement or undertaking fieldwork abroad being postgraduates. However the results of the research show numbers of undergraduates using the service are on the rise.

The number of staff requesting has fluctuated over the years but they remain a smaller group of requesters compared to students. The discussion in this research focuses more on distance students rather than distance learning staff (not to be confused with distance library staff) as students are our major requesting group, but it is acknowledged and encouraged that all staff involved in distance education can use the Distance Library Service. Building a relationship between distance library staff and distance faculty is advantageous for both parties, and especially as a way of improving students' knowledge and use of resources. 
Table 4. Qualifications Sought by Requesters

\begin{tabular}{lcccccc}
\hline Qualification & $\mathbf{2 0 0 7}$ & $\mathbf{2 0 0 8}$ & $\mathbf{2 0 0 9}$ & $\mathbf{2 0 1 0}$ & $\mathbf{2 0 1 1}$ & $\mathbf{2 0 1 2}$ \\
\hline Certificate of Proficiency & 0 & 0 & 0 & 5 & 4 & 4 \\
Diploma & 3 & 21 & 25 & 14 & 18 & 16 \\
Honours & 4 & 15 & 20 & 6 & 12 & 13 \\
Masters' Degree & 122 & 132 & 178 & 76 & 126 & 171 \\
National Certificate & 0 & 8 & 19 & 1 & 0 & 1 \\
Other & 6 & 5 & 5 & 2 & 2 & 2 \\
Postgraduate & 882 & 809 & 1022 & 245 & 429 & 574 \\
PhD & 122 & 129 & 166 & 87 & 111 & 142 \\
Post-doctorate & 0 & 0 & 0 & 1 & 1 & 1 \\
Staff & 46 & 56 & 72 & 27 & 50 & 60 \\
Undergraduate & 447 & 516 & 665 & 203 & 402 & 539 \\
(blank) & 14 & 62 & 99 & 95 & 65 & 60 \\
Total & $\mathbf{1 6 4 6}$ & $\mathbf{1 7 5 3}$ & $\mathbf{2 2 7 1}$ & $\mathbf{7 6 2}$ & $\mathbf{1 2 2 0}$ & $\mathbf{1 5 8 3}$ \\
\hline
\end{tabular}

Figure 5. Qualifications Sought by Requesters

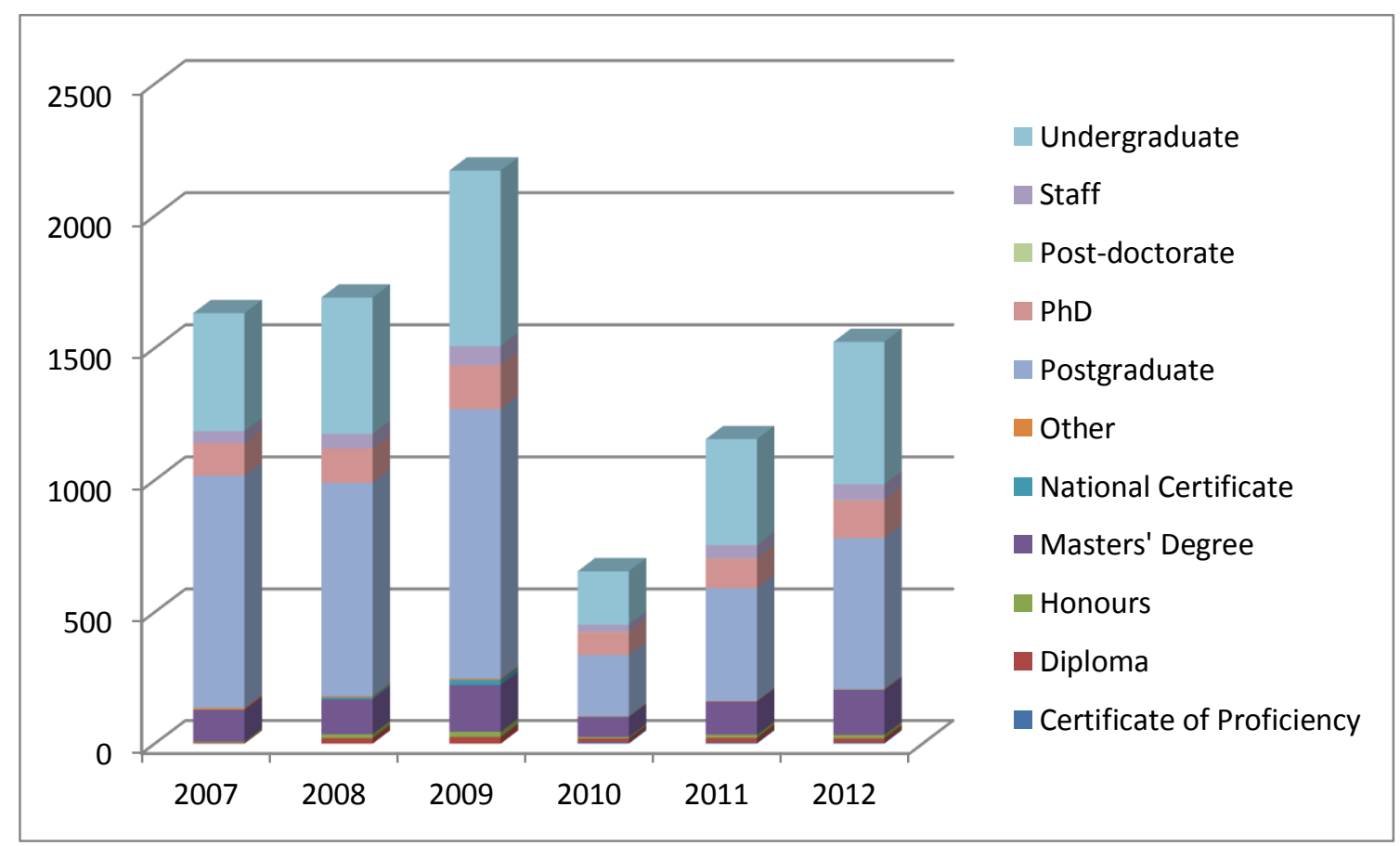


Figures 6 \& 7. Comparison of Qualifications Sought by Requesters
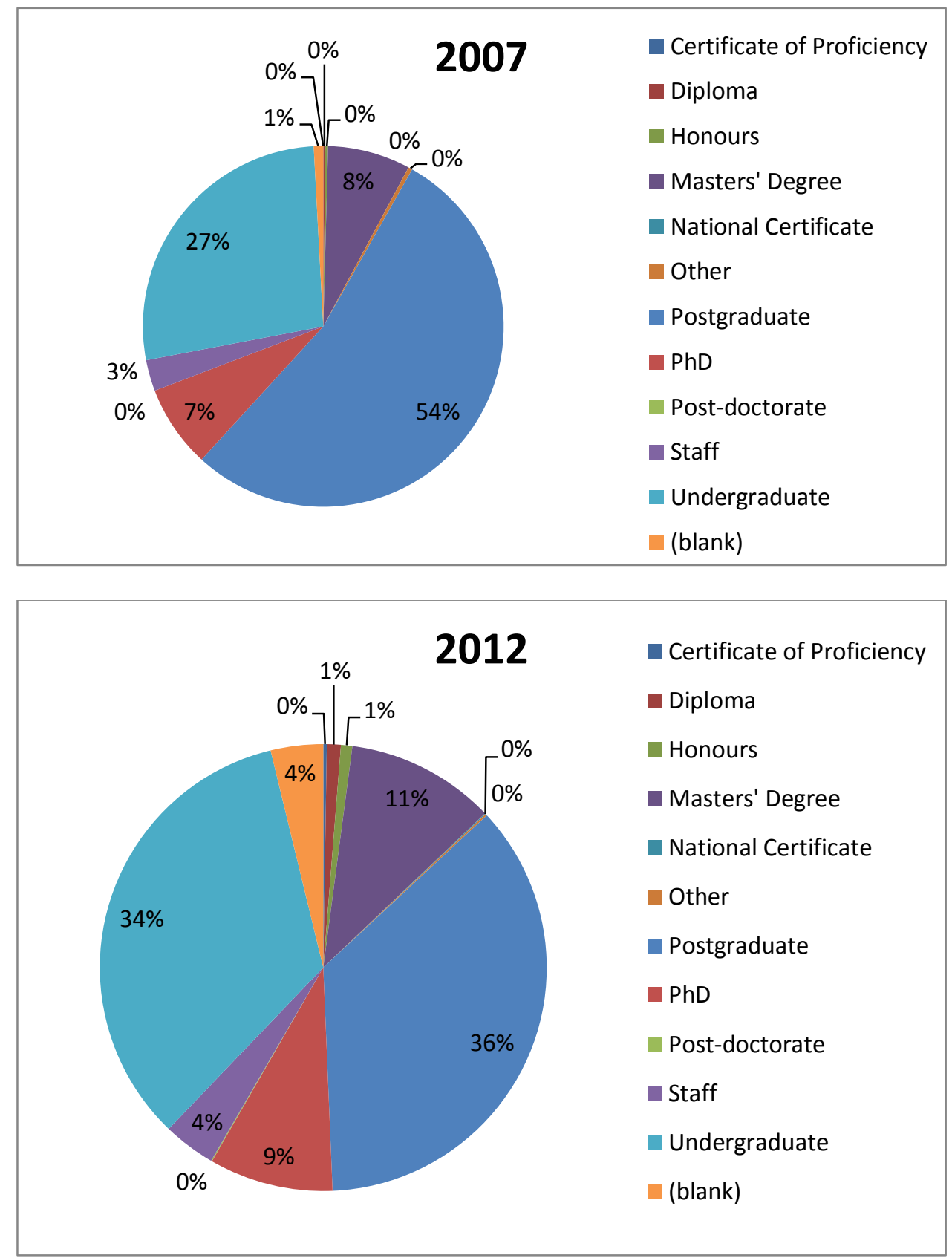

A major drawback with the qualifications results is that the way in which the qualification data was captured does not reflect the true number of active requesters. A truer count of actual active requesters was achieved in the previous section looking at number of requesters by institution.

Reasoning for the skewed results may be that distance requesters entered in the database were carried over from year to year causing a build-up of non-active "requesters". The only year to match the true results was 2010, which might also 
reflect an overhaul in service staff and starting afresh with the database between 2009 and 2010. In any case these results do show the varied levels of qualifications of distance requesters and hopefully provide a proportionate result, if not a true count. These results have emphasised the importance and complexity of maintaining accurate data over time.

\subsection{Characteristics of Users: Field of Study}

In a similarly problematic result to that above, the way in which requesters' fields of study was captured means they too could produce a skewed response. However in this case the subject areas can be gleaned from the request data and not the skewed requester data, except for the 2007 data. The total for 2007 represents the number of active and non-active requesters. Totals for 2008 - 2012 represent request data. This could be considered acceptable as we are concerned with quantity of requests per subject area for this part of the analysis.

Fields of study include subjects from both the University of Otago and the Otago Polytechnic. Quite a lot of work was involved in correcting misspellings, determining variations and grouping together the same subject areas. It was decided not to simplify or meld similar subjects in case of losing potentially enriching data. A more condensed list would require not only extensive familiarity with all subjects concerned but also more time than this research project could afford. The purpose of including this data is to show the most demanding fields of study for the Distance Library Service and the variety, which is achieved in this analysis.

Combining all requesting fields of study over the six years resulted in a considerable list of 120 different subject areas. 2010 was the most varied year covering 93 different fields. A full list of subject areas with quantity of requests received per subject per year is included in the Appendices. A smaller table showing the top five requested areas per year is displayed below. 
Table 5. Top Five Fields of Study

\begin{tabular}{lcccccc}
\hline Field of study & $\mathbf{2 0 0 7}$ & $\mathbf{2 0 0 8}$ & $\mathbf{2 0 0 9}$ & $\mathbf{2 0 1 0}$ & $\mathbf{2 0 1 1}$ & $\mathbf{2 0 1 2}$ \\
\hline Dental Bridging Course & $\mathrm{n} / \mathrm{a}$ & $\mathrm{n} / \mathrm{a}$ & 554 & $\mathrm{n} / \mathrm{a}$ & 401 & $\mathrm{n} / \mathrm{a}$ \\
Dietetics/Human Nutrition & 96 & $\mathrm{n} / \mathrm{a}$ & $\mathrm{n} / \mathrm{a}$ & $\mathrm{n} / \mathrm{a}$ & $\mathrm{n} / \mathrm{a}$ & $\mathrm{n} / \mathrm{a}$ \\
Education & $\mathrm{n} / \mathrm{a}$ & 768 & $\mathrm{n} / \mathrm{a}$ & 1065 & $\mathrm{n} / \mathrm{a}$ & 485 \\
Midwifery & $\mathrm{n} / \mathrm{a}$ & $\mathrm{n} / \mathrm{a}$ & $\mathrm{n} / \mathrm{a}$ & 648 & 1482 & 2168 \\
Nursing & 99 & 547 & 672 & $\mathrm{n} / \mathrm{a}$ & $\mathrm{n} / \mathrm{a}$ & $\mathrm{n} / \mathrm{a}$ \\
Occupational Therapy & $\mathrm{n} / \mathrm{a}$ & 807 & 715 & 573 & 638 & 477 \\
Physiotherapy & 81 & $\mathrm{n} / \mathrm{a}$ & $\mathrm{n} / \mathrm{a}$ & $\mathrm{n} / \mathrm{a}$ & $\mathrm{n} / \mathrm{a}$ & $\mathrm{n} / \mathrm{a}$ \\
Social Work \& Community Development & 100 & 629 & 616 & 692 & 464 & 496 \\
Theology & 147 & 2030 & 1692 & 1371 & 1090 & 1013 \\
All Other Courses & 1123 & 5764 & 6253 & 4783 & 4088 & 2658 \\
Total & $\mathbf{1 6 4 6}$ & $\mathbf{1 0 5 4 5}$ & $\mathbf{1 0 5 0 2}$ & $\mathbf{9 1 3 2}$ & $\mathbf{8 1 6 3}$ & $\mathbf{7 2 9 7}$ \\
\hline
\end{tabular}

The top five most demanding fields of study varies over the years, except for Social Work \& Community Development and Theology which are in the top five every year. Midwifery has made the most dramatic increase in requests over the years, from initially not appearing in the top five to being the most prolific requesting area. Only eighteen requests were received from Midwifery students in 2007 compared to 2,168 in 2012, representing almost a third of all requests received that year.

To offset the slight skew in numbers between 2007 and the remaining years, a series of charts are included which show the percentage of requests received per top five requested subjects. These charts emphasise the dominance of Theology, Social Work, and later Midwifery among the requested areas of study. They also show that the combined dominance of the top five requested subjects has grown from $32 \%$ to $64 \%$ of all requests. 
Figures 8-13. Comparison of Requests Received Per Top Five Fields of Study
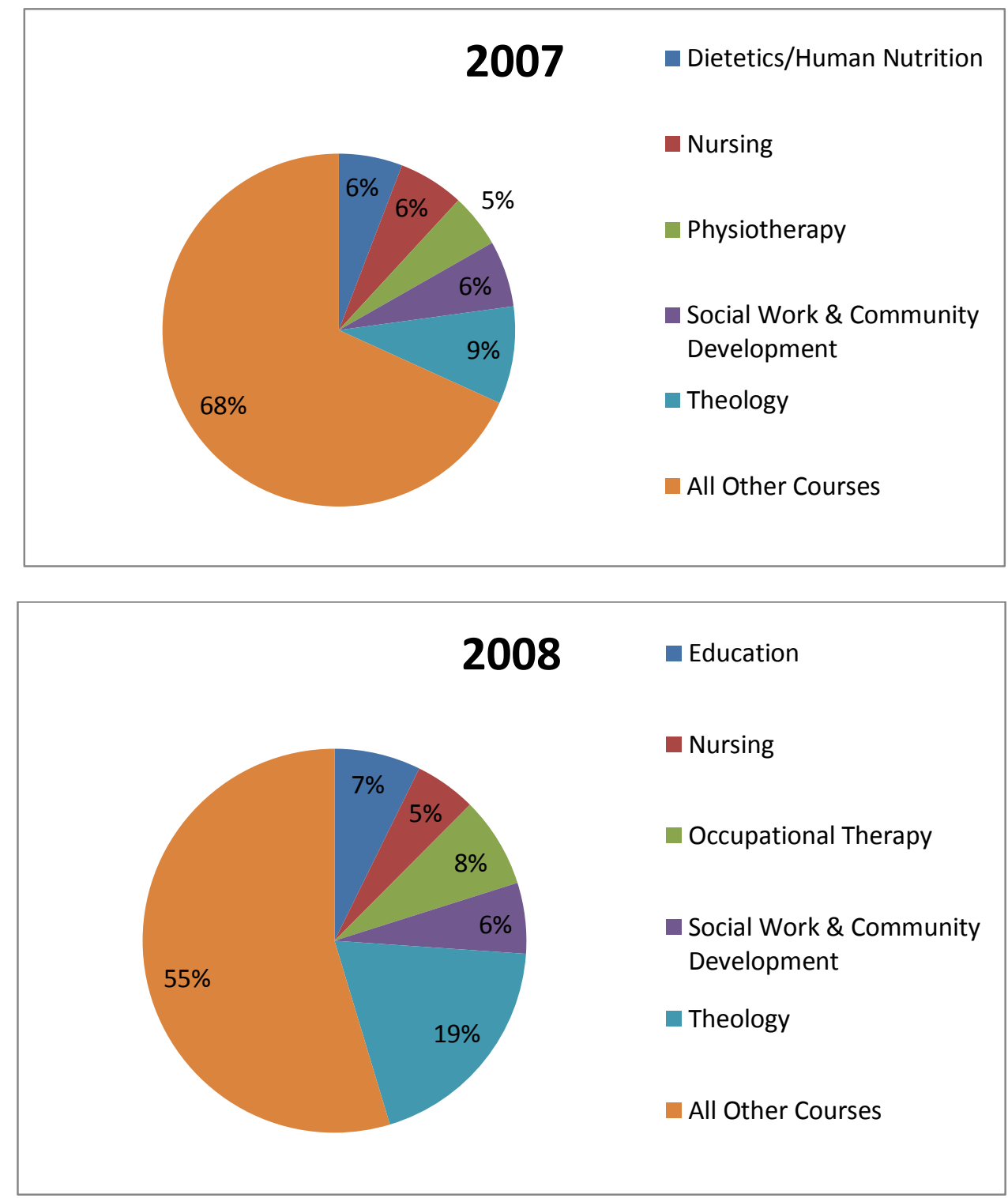

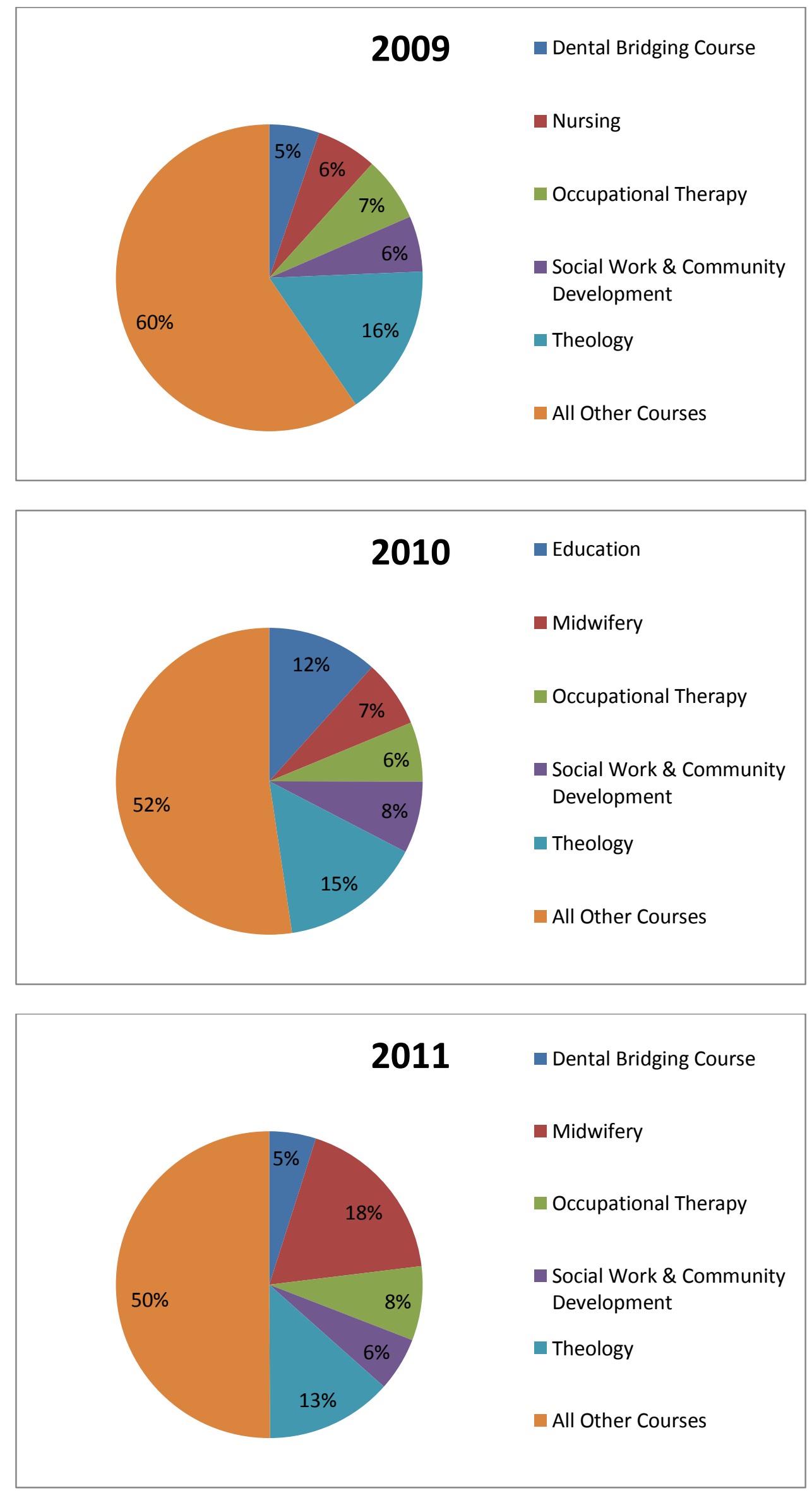


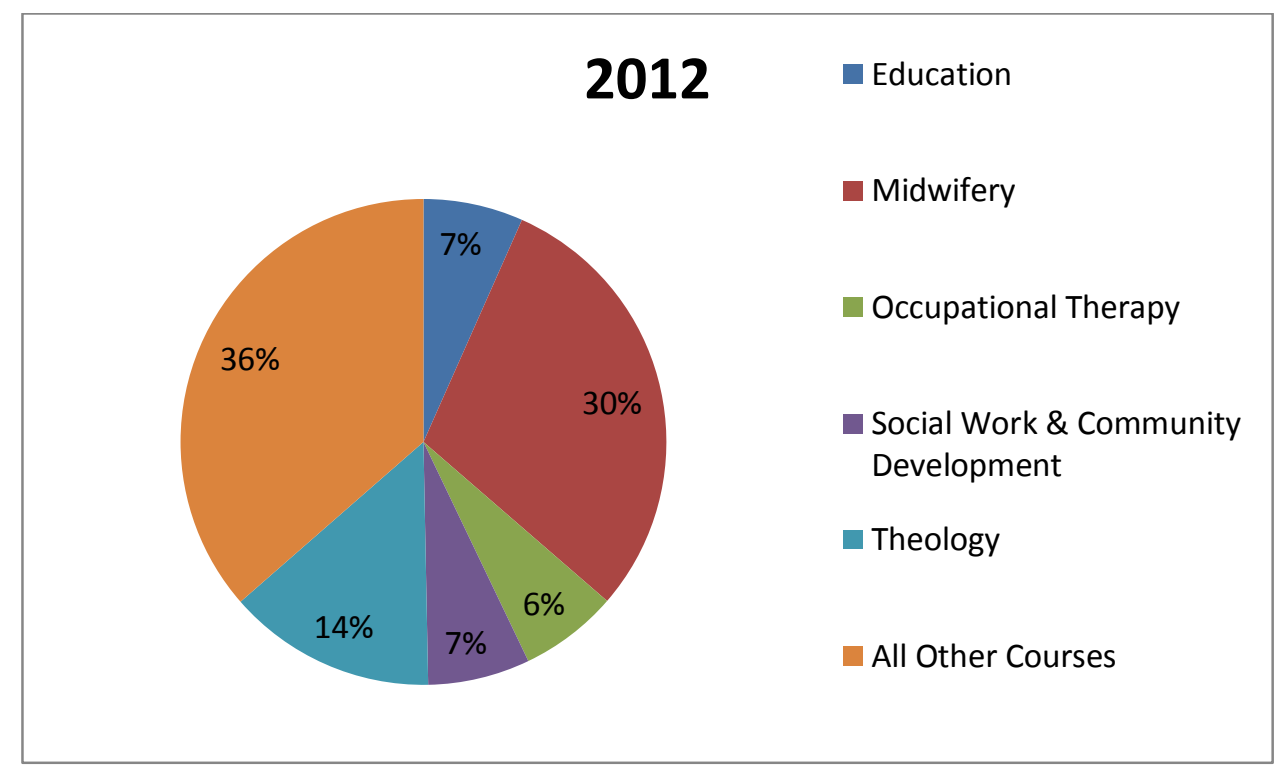

It is important to note that in the full list of subjects some fields are quite broad, for example: Health Sciences, Medicine, Consumer \& Applied Sciences, whereas others are more specific, for example: Oral Biology, Forensic Psychiatry, Clothing \& Textiles. Some fields only appear once for one request over the entire six years, for example: Botany, Chinese, Hospitality, whereas others appear every year with numerous requests, for example, Aviation Medicine, Ceramic Arts, and Marketing. Depending on the length of course of study we may have the same applicants for service over several years, or, we may have a requester enrolled in one or more fields over one or more years. Requesters are prompted to fill in their field of study and qualification sought when they fill in the online request form, our knowledge of these are dependent on receiving that information from the requester or by distance staff seeking clarification from a course advisor.

Abrupt increase or decrease in requests between years may be motivated by a new subject being introduced, an old subject abolished, reassigned a new title or merged with another subject, or it may rely on whether the subject is offered that year or offered by distance. Any Otago researcher undertaking their study elsewhere in New Zealand or abroad can apply to use the Distance Library Service which effectively means users can come from almost any discipline. 


\subsection{Discussion}

Unrecorded or unknown details comprise a very small amount which does not hugely affect results; however it is important to mention the following points which may have had an impact on the results:

$>$ Methods of recording have changed as Distance Library staff have changed

Services provided may have changed as staff have changed

$>$ The analysis relies on data already input into a database by many different people and its manipulation is restricted by how this has been captured within the database

Different terminology may be used by different library staff and by students

$>$ More than one type of request could be represented in a single statistic The Distance Library Service provides services and resources to both University of Otago and Otago Polytechnic staff and students. The service is primarily used by University postgraduate students but both undergraduate requests and Polytechnic requests are on the rise. Results of this research reveal the diversity of our users in qualification type and field of study.

Data collection of use of the service has been reduced to two categories of resources provided: copy and loan, effectively copies of journal articles or chapters, and loans of borrowable material. Distance staff are capable of providing much more than this and probably do, even if it is not recorded. Administrative types of requests such as renewals are no longer recorded among requests and may now be incorporated as part and parcel of unrecorded day-to-day activities of library staff.

Overall numbers of requests are decreasing, but this might be due to any number of different contributing factors including:

1. Recording of tasks has changed over time: been simplified, recorded elsewhere, taken for granted

2. Changes in recording over time may be due to new staff or lack of training

3. People may inadvertently record and report different information 
4. An increase in electronic content available through Library subscriptions or openly via the internet may mean students are sourcing material without staff intervention

Furthermore,

Staff rely on users and each other to record accurate information

$>$ Consistency and continuity of recording is important for meaningful results

$>$ Staff need to decide carefully what information is needed in a database and what information needs to come out

$>$ Staff training is important for consistency and continuity of good service Unfortunately, the basic data collected does not greatly elucidate the specific type of enquiries received. More detailed statistics would give a better snapshot of services and users than basic transaction statistics collected through the year. Basic statistics may sometimes be misleading as over the years changing staff will have different interpretations making comparison over time more difficult than first thought. However, the ability to trace trends in library services and library users over time, even for a service at a single institution still highlights those trends over time and the importance of assessing both use and usefulness of a service. Despite the challenges, these statistics offer important evidence of our involvement with our user community.

\section{Recommendations}

On the basis of the findings of this research it is recommended that the Distance Library Service could be improved by:

1. Establishing a set of guidelines for recording use and user data to ensure consistency and efficiency

2. Offering more specific training and support for distance library staff

3. Strengthening partnerships between distance library staff and faculties The distance library should be more than a factory operation where tasks are rotated to give staff variety. Distance learners are often disadvantaged in their access to resources and may need personalized service to compensate. Job satisfaction comes from the positive way students respond and rapport that is developed between users 
and library staff since for many distance learners, the library is the first and sometimes only contact with the university.

Strengths of the Distance Library Service include its resourcefulness, useful in today's climate of having to do more with what we already have, and in its relationships with the Otago Distance Learning Office, the University and the Polytechnic. Its weaknesses lie in its lack of promotion, not only of its services and resources but also its usage data which could be adopted to demonstrate the quantity and variety of users, and reaffirm relevance to the university. Strengthening relationships with other university staff will also help the distance library better understand how to contribute more significantly to student and staff success.

This research aimed to explore use of the Distance Library Service by looking at requests received and processed by the service over a six-year period, attempting to reveal trends in library services and library users over time. Further research could be conducted in the following way:

$>$ Combine and compare this data with survey data, from either one or both of the surveys carried out by the Distance Learning Office and University of Otago

$>$ Measure the data against hard evidence of use of distance library services at another New Zealand tertiary institution

Expand the current analysis by including data prior to 2007, or more recent data

\section{Conclusion}

At the time of writing, the University of Otago Library is implementing a new library management system that may mean the end of the current system for recording data for the Distance Library Service. It is imperative that efficient and effective recording of use and user data continues, in an ideal world it would be automated, but it also needs to be recorded in a way which meaningful data can be easily extracted and employed to validate and emphasise the truly remarkable services and resources the library provides. 
The purpose of this study was to examine and review the use of a Distance Library Service, assess strengths and weaknesses of its use, and identify areas to improve on and develop. The research exposed changes over time in requests made to the Distance Library Services staff as well as characteristics of users of the service. By analysing these features the study hopes to offer a better understanding of the service and its users that can contribute to a more complete picture of trends which may assist in future planning and directives of the library.

The library as an extension of the university must be studied as to its ability to move forward and to be technologically competitive in an increasingly informationtechnology-driven society (Brumfield, 2010, p.64). Traditional means of measuring value focused on book inventories and number of staff have been superseded by a new focus on a better understanding of our users and what resources are needed to support effective teaching and learning. 


\section{References}

Agorogianni, A. Z., Zaharis, Z. D., Anastasiadou, S. D., \& Goudos, S. K. (2011). Distance learning technology and service support in Greece: the case study of the Aristotle University over the last decade. Education and Information Technologies, 16(1), 25-39. doi: 10.1007/s10639-009-9110-3

Alewine, M. C. (2012). Listen to what they have to say! Assessing distance learners' satisfaction with library services using a transactional survey. Journal of Library \& Information Services in Distance Learning, 6(3/4), 136-146. doi:10.1080/1533290X.2012.705103

Anderson, B. (2010). State of the "distance" nation. DEANZ magazine: engaging with open, flexible and distance education in all sectors of New Zealand, August. Lower Hutt, New Zealand: Distance Education Association of New Zealand. Retrieved July 28, 2013, from http://www.deanz.org.nz/home/images/newsletters/November10.pdf

Anderson, B. (2012). Distance Learning Students Access to Technology Survey 2012. University of Otago. November 2012.

Anderson, B. (2013). Welcome to Otago's distance learning programme. In University of Otago, Distance Learning Prospectus 2013 (p.1). Retrieved February 10, 2014, from http://www.otago.ac.nz/courses/distance_study/otago034402.pdf

Association of College and Research Libraries, American Library Association. (2008). Guidelines for distance learning library services. Retrieved May 16, 2013, from http://www.ala.org/acrl/standards/guidelinesdistancelearning

Barrett, J. (2011). Introduction. In J. Barrett (Ed.) Open learning for an open world: reflections on open and distance learning and teaching at the Open Polytechnic of New Zealand (pp.9-12). Lower Hutt: The Open Polytechnic of New Zealand. Retrieved April 16, 2013, from 
https://www.openpolytechnic.ac.nz/assets/Research/Open-Learning-for-anOpen-World.pdf

Bower, S. L., \& Mee, S. A. (2010). Virtual delivery of electronic resources and services to off-campus users: a multifaceted approach. Journal of Library Administration, 50(5/6), 468-483. doi:10.1080/01930826.2010.488593

Brumfield, E. J. (2010) Applying the critical theory of library technology to distance library services. Journal of Library \& Information Services in Distance Learning, 4(1-2), 63-71. doi: 10.1080/15332901003765795

Cassner, M. \& Adams, K. E. (2004). A survey of distance librarian-administrators in ARL Libraries: an overview of library resources and services. Journal of Library Administration, 41(1-2), 85-96. doi: 10.1300/J111v41n01_08

Cleveland-Innes, M. F. \& Sangra, A. (2010). Leadership in a new era. In M. F. ClevelandInnes \& D. R. Garrison (Eds.) An Introduction to distance education: understanding teaching (pp.235-242). Hoboken: Taylor and Francis.

Cooke, N. A. (2005) The Role of libraries in web-based distance education. Journal of Library \& Information Services in Distance Learning, 1(4), 47-57. doi: 10.1300/J192v01n04_04

Cox, B. \& Jantti, M. (2012). Discovering the impact of library use and student performance. Educause Review Online. Retrieved January 30. 2014 from http://www.educause.edu/ero/article/discovering-impact-library-use-andstudent-performance

Distance Learning Office. (2008). Distance Learning Technologies Access Survey October 2008. Dunedin, Distance Learning Office.

Fisher, J. (2005). Is IT a problem? Computer literacy and the distance student. Unpublished MLIS research project, Victoria University of Wellington, Wellington, New Zealand. 
Fritts, J., \& Casey, A. (2010). Who trains distance librarians? A study of the training and development needs of distance learning librarians. Journal of library administration, 50(5/6), 617-627. doi:10.1080/01930826.2010.488925

Graham, J. (2009). An Uneven balancing act: one library administrator's view on providing library services for distant patrons. Journal of Library \& Information Services in Distance learning, 3(2), 43-46. doi: 10.1080/15332900903057899

Grant, R., Olivier, G., Rawlings, C., \& Ross, C. (2011). Enhancing the engagement and success of distance students through targeted support programmes. In J. Barrett (Ed.) Open learning for an open world: reflections on open and distance learning and teaching at the Open Polytechnic of New Zealand (pp.159-180). Lower Hutt: The Open Polytechnic of New Zealand. Retrieved April 16, 2013, from https://www.openpolytechnic.ac.nz/assets/Research/Open-Learning-for-anOpen-World.pdf

Hafner, A. W. (1998). Descriptive statistical techniques for librarians. 2nd edition. Chicago; London: American Library Association.

Hayne, H. (2013). Welcome to the University of Otago. In University of Otago, Distance Learning Prospectus 2013 (p.1). Retrieved February 10, 2014, from http://www.otago.ac.nz/courses/distance_study/otago034402.pdf

Herring, S. D. (2010). Research on libraries and distance education: an analysis of articles published 1999-2009. Journal of Library and Information Services in Distance Learning, 43(3), 137-146. doi: 10.1080/1533290X.2010.503494

Holloway, K. (2008). ILLiad, document delivery, and the distance student: how document delivery can enhance support for distance library users. Journal of Library Administration, 48(3/4), 479-493. Retrieved April 10, 2013, from Ebscohost.

Holloway, K. (2011) Outreach to distance students: a case study of a new distance librarian. Journal of Library \& Information Services in Distance Learning, 5(1-2), 25-33. doi: 10.1080/1533290X.2011.548231 
Kelley, K. B. \& Orr, G. J. (2003). Trends in distant student use of electronic resources: a survey. College \& Research Libraries, 64(3), 176-191. Retrieved October 15, 2012, from Ebscohost.

Kyrillidou, M. (2002). From input and output measures to quality and outcome measures, or, from the user in the life of the library to the library in the life of the user. Journal of Academic Librarianship, 28(1/2), 42-46. Retrieved April 30, 2013, from Ebscohost.

Lee, L. (2008). Reference services for students studying by distance. Unpublished MLIS research project, Victoria University of Wellington, Wellington, New Zealand.

Massis, B. E. (2013). What's new in libraries: MOOCs and the library. New Library World, 114(5/6), 267-270. doi: 10.1108/03074801311326894

Ministry of Education. (2010a). Education Counts. Statistics. Participation. Retrieved April 6, 2013, from http://www.educationcounts.govt.nz/statistics/tertiary_education/participation

Ministry of Education, (2010b). Tertiary Education Strategy 2010-2015. Wellington: Ministry of Education. Retrieved January 28, 2014, from http://www.minedu.govt.nz/NZEducation/EducationPolicies/TertiaryEducation/P olicyAndStrategy/TertiaryEducationStrategy.aspx

Mirosa, R. (2011). Student Opinion Survey 2011. Dunedin, Quality Advancement Unit.

Mohssin, I. \& AL-Ahmad, N. (2005). The Role of information technology in building up knowledge economy producting and using information in libraries and information centers. Journal of Social Sciences 1(4), 203-210. doi: $10.3844 /$ jssp.2005.203.210

Moyo, L. M. \& Cahoy, E. S. (2003). Meeting the needs of remote library users. Library Management, 24(6/7), 281-290. doi: 10.1108/0143512031048599 
Needham, G., \& Johnson, K. (2007). Ethical issues in providing library services to distance learners. Open Learning, 22(2), 117-128. doi:

$10.1080 / 02680510701306657$

Needham, G., Nurse, R., Parker, J., Scantlebury, N., \& Dick, S. (2013). Can an excellent distance learning library service support student retention and how can we find out? Open Learning: The Journal of Open, Distance and e-Learning, 28(2), 135140. doi: $10.1080 / 02680513.2013 .847364$

Nichols, J. T. (2006). Monthly check-up: using a monthly survey to monitor and assess library and information services for distance learners. Journal of Library Administration, 45, 387-95. Retrieved April 10, 2013, from Ebscohost.

Nickel, L. T. \& Mulvihill, R. G. (2010). Serving unaffiliated distance learners: strategies that work. Journal of Library \& Information Services in Distance Learning, 4(3), 87-95. doi: 10.1080/1533290X.2010.503495

Oakleaf, M. (2010). Value of academic libraries: a comprehensive research review and report. Association of College and Research Libraries (ACRL). Retrieved January 30, 2014 from http://www.ala.org/acrl/sites/ala.org.acrl/files/content/issues/value/val_report. pdf

Olivas, A. P., \& Chan, I. (2013). Beyond the reference desk: a study on the effectiveness of low-cost distance library services at California State University San Marcos. Journal of Library \& Information Services in Distance Learning, 7(1/2), 40-52. doi:10.1080/1533290X.2012.705177

Pitts , J., Coleman, J. \& Bonella, L. (2013). Using distance patron data to improve library services and cross-campus collaboration. Internet Reference Services Quarterly, 18(1), 55-75. doi: 10.1080/10875301.2013.800014

Poskitt, J., Rees, M. \& Suddaby, G. (2011). Engaging with university at a distance: the differences in levels of student engagement among extramural and campusbased students. In Radloff, A. (Ed.) Student engagement in New Zealand's 
universities (pp.70-76). Melbourne: Australian Council for Educational Research. Retrieved July 30, 2013 from http://research.acer.edu.au.ezproxy.otago.ac.nz/ausse/14/

Prebble, T. (2010). From a Distance: 50th Jubilee of Distance Learning. Palmerston North: Massey University.

Primus, S. (2009). Distance learning library services. Distance Learning, 6(1), 22-26. Retrieved May 16, 2013, from http://itde.nova.edu/Resources/uploads/app/43/files/itde/students_scholarship /DLarticles/Simone_Primis.pdf

Radloff, A. (Ed.) (2011). Student engagement in New Zealand's universities. Melbourne: Australian Council for Educational Research. Retrieved July 30, 2013, from http://research.acer.edu.au.ezproxy.otago.ac.nz/ausse/14/

Radloff, A. \& Coates, H. (2011). Introduction. In Radloff, A. (Ed.) Student engagement in New Zealand's universities (pp.v-xv). Melbourne: Australian Council for Educational Research. Retrieved July 30, 2013, from http://research.acer.edu.au.ezproxy.otago.ac.nz/ausse/14/

Selwyn, N. (2011). Digitally distanced learning: a study of international distance learners' (non)use of technology. Distance Education, 32(1), 85-99. doi: $10.1080 / 01587919.2011 .565500$

Shillington, S., Brown, M., MacKay, A., Paewai, S., Suddaby, G., \& White, F. (2012). Avoiding the goulash: closing gaps and bridging distances. Open Learning, 27(1), 65-80. doi:10.1080/02680513.2012.640789

Stone, G., Ramsden, B., \& Pattern, D. (2011). Looking for the link between library usage and student attainment. Ariadne, 67. Retrieved December 10, 2013, from http://www.ariadne.ac.uk/issue67/stone-et-al/

Tripathi, M. \& Jeevan, V. K. J. (2009). Quality assurance in distance learning libraries. Quality Assurance in Education, 17(1). doi: 10.1108/09684880910929926 
University of Otago. (2012). Annual Report 2012. Retrieved January 30, 2014, from http://www.otago.ac.nz/about/otago045429.pdf

University of Otago. (2013a). Distance learning information and support including a guide to library services. Retrieved February 10, 2014, from http://www.hein.otago.ac.nz/resources/DistancelearningHandbook.pdf

University of Otago. (2013b). Quick statistics. Student Facts \& Figures. Retrieved April 10, 2013 from http://www.otago.ac.nz/about/quickstats.html

University of Otago. (2013c). Quick statistics. Library. Retrieved April 10, 2013 from http://www.otago.ac.nz/about/quickstats.html\#library

University of Otago. (2013d). University of Otago Strategic Direction to 2020. Retrieved January 30, 2014, from http://www.otago.ac.nz/otago053226.pdf

University of Otago. (2014a). How distance learning works at Otago. Retrieved January 28,2014 , from http://www.otago.ac.nz/courses/distance_study/otago011623.html

University of Otago. (2014b). Quick Statistics. Student Facts \& Figures. Retrieved January 30, 2014 from http://www.otago.ac.nz/about/quickstats.html

University of Otago. (2014c). Terminology. Retrieved January 28, 2014, from http://www.otago.ac.nz/study/terms.html\#d

Vare, L. S. (2002). Library services for distance education in New Zealand tertiary institutions: do we need national guidelines? Unpublished MLIS research project, Victoria University of Wellington, Wellington, New Zealand.

Watson, E. F. \& Jagannathan, N. (Eds.) (1996). Library services to distance learners in the Commonwealth: a reader. Vancouver: the Commonwealth of Learning.

White, B. (2011). Your books are in the mail: fifty years of distance library service at Massey University. Palmerston North: Massey University Library.

Whitehead, D. (2007). Why have statistics? ... and what? [PowerPoint slides]. Retrieved from 
http://www.caul.edu.au/content/upload/files/datasets/usagestatistics2007whit ehead.pdf

Wooliscroft, M. (1996). Introduction. In E. F. Watson \& N. Jagannathan (Eds.) Library services to distance learners in the Commonwealth: a reader (pp. 1-8).

Vancouver: the Commonwealth of Learning. 


\section{Appendices}

\section{Appendix 1: Further Tables}

Table 6. Categories Used for Coding

\begin{tabular}{|c|c|c|}
\hline $\begin{array}{l}\text { Category Entry } \\
\text { in Filemaker }\end{array}$ & Description & $\begin{array}{c}\text { Category } \\
\text { Assigned for } \\
\text { Analysis }\end{array}$ \\
\hline Article & Journal article downloaded and emailed or printed and posted to user & Copy \\
\hline AV & Audiovisual item (DVD/video) posted to user & Loan \\
\hline Book & Book posted to user & Loan \\
\hline Cancel/Dup & Request from user cancelled or duplicated & Cancelled \\
\hline CDRom & CDRom posted to user & Loan \\
\hline Chapter & Chapter of book scanned and emailed or photocopied and posted to user & Copy \\
\hline Copy & Article or chapter emailed or posted to user & Copy \\
\hline Debt 2007 & Help with clearing debt from fines, fees or invoices from 2007 (only used 2008) & Help \\
\hline ERIC & Help with accessing online resources from Education Resources Information Center & Help \\
\hline Exam & Requester directed to online past exam paper(s) or past exam(s) sent to user & Help \\
\hline Fines & Advice given to user on how to pay fines & Help \\
\hline Info/Help & Any kind of relevant help or information given to user & Help \\
\hline Invoice & Invoice sent to user & Help \\
\hline IT Support & Query passed to IT staff or technical support given & Help \\
\hline Loan & Borrowable item issued and posted to user & Loan \\
\hline No Lists & User advised not to send lists of requests on one form & Help \\
\hline OD/Recall & Query involving complaint, alert of or help with overdue or recalled item(s) & Help \\
\hline Password & New password input into user's account & Help \\
\hline PG Guide & User sent a postgraduate study guide or directed to online guide & Help \\
\hline Ref & Help with citation or citation style & Help \\
\hline Ref Help & Help with citation or citation style & Help \\
\hline Registration & Registration of user with Distance Library Service & Help \\
\hline Rem Access & Help with accessing items remotely & Help \\
\hline Renewal & Renewal of item(s) on loan to user & Help \\
\hline Req Form & User sent Distance Library Request Form in mail or directed to use Online Request Form & Help \\
\hline Re-Send & Re-sending of requested item to user & Help \\
\hline Search & Help given with searching library catalogue or databases & Help \\
\hline Search Asst & Help given with searching library catalogue or databases & Help \\
\hline Thesis & Copy of thesis sent to user & Copy \\
\hline TOC & Table of contents sent to user & Help \\
\hline Unknown & No details recorded for request & Cancelled \\
\hline Visit & Face-to-face visit with user & Visit \\
\hline
\end{tabular}


Table 7. Quantities of Requests Per Fields of Study Per Year

\begin{tabular}{|c|c|c|c|c|c|c|}
\hline Field of study & 2007 & 2008 & 2009 & 2010 & 2011 & 2012 \\
\hline Academic Communication & 0 & 17 & 0 & 0 & 6 & 0 \\
\hline Accounting & 0 & 11 & 1 & 0 & 0 & 3 \\
\hline Acupuncture & 5 & 82 & 17 & 19 & 34 & 0 \\
\hline Advanced Family Practice & 0 & 8 & 0 & 0 & 0 & 0 \\
\hline Anatomy and Structural Biology & 1 & 0 & 2 & 47 & 38 & 20 \\
\hline Anthropology & 3 & 48 & 68 & 31 & 8 & 3 \\
\hline Applied Management & 0 & 0 & 5 & 8 & 9 & 8 \\
\hline Archaeology & 1 & 0 & 3 & 0 & 8 & 7 \\
\hline Art History & 3 & 25 & 28 & 28 & 23 & 0 \\
\hline Asian Studies & 0 & 0 & 48 & 17 & 13 & 12 \\
\hline Aviation Medicine & 27 & 204 & 140 & 48 & 27 & 25 \\
\hline Biochemistry & 3 & 20 & 8 & 3 & 2 & 0 \\
\hline Bioethics & 7 & 5 & 47 & 76 & 63 & 90 \\
\hline Biological Anthropology & 0 & 0 & 0 & 0 & 50 & 0 \\
\hline Biomedical Technology & 1 & 0 & 0 & 0 & 0 & 0 \\
\hline Botany & 0 & 0 & 0 & 0 & 0 & 1 \\
\hline Business & 17 & 0 & 24 & 11 & 5 & 22 \\
\hline Ceramic Arts & 12 & 71 & 126 & 33 & 117 & 14 \\
\hline Certificate in Health & 0 & 0 & 0 & 14 & 0 & 130 \\
\hline Chemistry & 4 & 2 & 11 & 0 & 0 & 0 \\
\hline Child Health & 24 & 6 & 39 & 16 & 16 & 4 \\
\hline Children's Issues & 52 & 127 & 239 & 28 & 16 & 0 \\
\hline Chinese & 0 & 1 & 0 & 0 & 0 & 0 \\
\hline Civil Engineering/Architecture & 0 & 1 & 0 & 0 & 0 & 0 \\
\hline Classics & 2 & 0 & 193 & 60 & 0 & 20 \\
\hline Clothing \& Textiles & 8 & 1 & 33 & 23 & 13 & 1 \\
\hline Commerce & 13 & 5 & 1 & 8 & 1 & 0 \\
\hline Community Nutrition & 23 & 145 & 99 & 24 & 26 & 3 \\
\hline Consumer \& Applied Sciences & 0 & 0 & 0 & 0 & 0 & 12 \\
\hline Culinary Arts & 0 & 0 & 0 & 0 & 0 & 42 \\
\hline Dance & 1 & 0 & 0 & 0 & 0 & 0 \\
\hline Dental Bridging Course & 32 & 244 & 554 & 172 & 401 & 13 \\
\hline Dental Technology & 6 & 21 & 0 & 35 & 28 & 35 \\
\hline Dentistry & 11 & 54 & 163 & 136 & 83 & 36 \\
\hline Design & 0 & 0 & 0 & 2 & 0 & 12 \\
\hline Dietetics/Human Nutrition & 96 & 428 & 413 & 224 & 227 & 94 \\
\hline Ecology & 1 & 10 & 0 & 0 & 0 & 0 \\
\hline Education & 56 & 768 & 527 & 1065 & 342 & 485 \\
\hline English & 7 & 27 & 6 & 11 & 0 & 1 \\
\hline Entrepreneurship & 0 & 14 & 35 & 6 & 12 & 12 \\
\hline Evidence Informed Practice & 0 & 0 & 0 & 0 & 4 & 0 \\
\hline Fashion Design & 0 & 0 & 3 & 0 & 0 & 0 \\
\hline Film Studies & 3 & 26 & 8 & 11 & 12 & 0 \\
\hline Fine Arts & 1 & 6 & 4 & 11 & 2 & 1 \\
\hline Forensic Pyschiatry & 0 & 0 & 0 & 0 & 0 & 1 \\
\hline French & 1 & 2 & 0 & 0 & 0 & 0 \\
\hline Gender & 0 & 3 & 21 & 1 & 0 & 0 \\
\hline General Practice \& Rural Health & 28 & 70 & 150 & 53 & 66 & 16 \\
\hline Genetics & 0 & 1 & 11 & 19 & 21 & 0 \\
\hline Geography & 5 & 45 & 25 & 16 & 3 & 0 \\
\hline Geology & 3 & 4 & 1 & 2 & 0 & 0 \\
\hline German & 0 & 16 & 10 & 6 & 0 & 0 \\
\hline Health Sciences & 54 & 195 & 237 & 469 & 231 & 203 \\
\hline History & 5 & 15 & 139 & 61 & 46 & 34 \\
\hline
\end{tabular}




\begin{tabular}{|c|c|c|c|c|c|c|}
\hline Horticulture & 0 & 2 & 0 & 0 & 2 & 1 \\
\hline Hospitality & 0 & 0 & 0 & 0 & 1 & 0 \\
\hline Indigenous Studies & 4 & 141 & 6 & 86 & 135 & 11 \\
\hline Industrial Health & 0 & 0 & 0 & 21 & 0 & 1 \\
\hline Information Science & 4 & 1 & 0 & 0 & 0 & 0 \\
\hline International Studies & 2 & 16 & 65 & 5 & 1 & 0 \\
\hline Law & 4 & 29 & 48 & 93 & 71 & 45 \\
\hline Linguistics & 0 & 0 & 156 & 235 & 200 & 223 \\
\hline Management & 4 & 39 & 132 & 55 & 16 & 0 \\
\hline Maori Studies & 0 & 0 & 0 & 25 & 1 & 12 \\
\hline Marine Science & 5 & 58 & 3 & 11 & 1 & 0 \\
\hline Marketing & 17 & 123 & 66 & 150 & 31 & 6 \\
\hline Maths \& Stats & 1 & 30 & 50 & 8 & 5 & 1 \\
\hline Medical Laboratory Science & 8 & 17 & 17 & 20 & 5 & 1 \\
\hline Medical Technology & 5 & 1 & 116 & 19 & 2 & 0 \\
\hline Medicine & 63 & 113 & 234 & 176 & 225 & 147 \\
\hline Microbiology & 2 & 0 & 3 & 0 & 0 & 0 \\
\hline Midwifery & 18 & 425 & 236 & 648 & 1482 & 2168 \\
\hline Ministry & 0 & 185 & 187 & 97 & 95 & 43 \\
\hline Musculoskeletal Medicine & 27 & 61 & 21 & 46 & 26 & 111 \\
\hline Music & 1 & 4 & 19 & 29 & 117 & 48 \\
\hline Natural History Film Making & 1 & 2 & 0 & 0 & 0 & 0 \\
\hline Nursing & 99 & 547 & 672 & 143 & 211 & 323 \\
\hline Obstetrics \& Gynaecology & 7 & 16 & 19 & 0 & 0 & 1 \\
\hline Occupational Health & 16 & 0 & 23 & 15 & 98 & 37 \\
\hline Occupational Therapy & 35 & 807 & 715 & 573 & 638 & 477 \\
\hline Ophthalmology & 5 & 1 & 17 & 37 & 25 & 2 \\
\hline Oral Biology & 0 & 29 & 19 & 0 & 5 & 0 \\
\hline Pacific Studies & 0 & 0 & 2 & 0 & 0 & 0 \\
\hline Paediatrics & 0 & 0 & 0 & 4 & 0 & 0 \\
\hline Pathology & 6 & 3 & 21 & 2 & 1 & 4 \\
\hline Peace and Conflict Studies & 0 & 0 & 0 & 9 & 62 & 63 \\
\hline Pharmacology & 2 & 5 & 7 & 8 & 2 & 0 \\
\hline Pharmacy & 40 & 53 & 51 & 17 & 27 & 11 \\
\hline Philosophy & 2 & 39 & 19 & 5 & 30 & 48 \\
\hline Physical Education & 15 & 27 & 19 & 92 & 65 & 60 \\
\hline Physics & 1 & 1 & 0 & 0 & 18 & 0 \\
\hline Physiotherapy & 81 & 479 & 265 & 329 & 339 & 88 \\
\hline Planning & 0 & 0 & 0 & 1 & 0 & 0 \\
\hline Political Studies & 5 & 40 & 22 & 2 & 19 & 5 \\
\hline Preventive and Social Medicine & 1 & 0 & 11 & 0 & 0 & 1 \\
\hline Primary Health Care & 0 & 3 & 7 & 0 & 2 & 34 \\
\hline Psychological Medicine & 33 & 156 & 81 & 35 & 5 & 10 \\
\hline Psychology & 7 & 49 & 68 & 9 & 0 & 0 \\
\hline Public Health & 32 & 316 & 107 & 100 & 116 & 61 \\
\hline Radiation Therapy & 3 & 3 & 2 & 2 & 2 & 0 \\
\hline Rehabilitation & 62 & 225 & 217 & 303 & 95 & 61 \\
\hline Religious Studies & 0 & 0 & 88 & 119 & 83 & 84 \\
\hline Resuscitation & 5 & 0 & 0 & 2 & 0 & 0 \\
\hline Science & 2 & 8 & 15 & 9 & 6 & 9 \\
\hline Science Communication & 0 & 0 & 0 & 0 & 12 & 10 \\
\hline Social Work \& Community Development & 100 & 629 & 616 & 692 & 464 & 496 \\
\hline Sports Medicine & 60 & 176 & 289 & 172 & 44 & 39 \\
\hline Sports Studies & 67 & 269 & 166 & 106 & 96 & 45 \\
\hline Stonemasonry & 0 & 0 & 0 & 1 & 0 & 0 \\
\hline Surgery & 0 & 0 & 0 & 1 & 0 & 0 \\
\hline Surveying & 0 & 0 & 0 & 1 & 0 & 0 \\
\hline Sustainable Practice & 0 & 0 & 0 & 1 & 1 & 18 \\
\hline
\end{tabular}




\begin{tabular}{lcccccc} 
Theatre Studies & 0 & 0 & 7 & 13 & 0 & 12 \\
Theology & 147 & 2030 & 1692 & 1371 & 1090 & 1013 \\
Therapeutic Massage & 0 & 0 & 0 & 0 & 42 & 0 \\
Tourism & 76 & 359 & 241 & 52 & 57 & 38 \\
Travel \& Tropical Medicine & 14 & 67 & 42 & 51 & 11 & 6 \\
Veterinary Nursing & 11 & 56 & 53 & 15 & 20 & 47 \\
Wilderness medicine & 3 & 13 & 4 & 2 & 0 & 0 \\
Zoology & 6 & 42 & 3 & 3 & 0 & 1 \\
(blank) & 21 & 122 & 124 & 317 & 108 & 15 \\
Total & $\mathbf{1 6 4 6}$ & $\mathbf{1 0 5 4 5}$ & $\mathbf{1 0 5 0 2}$ & $\mathbf{9 1 3 2}$ & $\mathbf{8 1 6 3}$ & $\mathbf{7 2 9 7}$ \\
\hline
\end{tabular}


Appendix 2: Participant Information Sheet 


\section{Participant Information Sheet}

Research Project Title: Measuring use of a Distance Library Service: a case study at the University of Otago

Researcher: Jacinta Beckwith, School of Information Management, Victoria University of Wellington

As part of the completion of my Master of Information Studies degree, I am undertaking a research project to investigate use of a distance library service using the University of Otago Library as a case study. Hard evidence of use of the service represented by user requests received and processed by University of Otago Distance Library Service staff between 2007 and 2012 will be examined. A study of geographic locations, level of study and subject area of requesters will provide a richer picture for the investigation.

Information will also be gathered from interviews with University of Otago Library staff who were part of the University of Otago Distance Library Service between 2007 and 2012. The purpose of the interviews is to discuss findings of the initial data analysis and gain further perspective of the Distance Library Service and its users. From this study I hope to identify changes in use of the service over time, expose valuable evidence that can contribute to future planning and improvement of services and broaden awareness of our information services and our clients.

Victoria University requires, and has granted, approval from the School's Human Ethics Committee.

I am inviting University of Otago Library staff who have been part of the University of Otago Distance/Remote Library Service between 2007 and 2012 to participate in this research. Participants will be asked to take part in a 20-30 minute interview. Notes will be taken by the researcher during the interview.

Participation is voluntary, and you will not be identified personally in any written report produced as a result of this research. As the organisation will be identified, it may be possible to determine your identity from quotations used, though every attempt will be made to limit this possibility. All material collected will be kept confidential, and will be viewed only by myself and by my supervisor Professor Anne Goulding. The research report will be submitted for marking to the School of Information Management, and subsequently deposited in the University Library. Participants will be provided with a link to the electronic copy of the completed research report once deposited in the Victoria University of Wellington Research Archive. Should any participant wish to withdraw from the project, they may do so until 
December 31, 2013, and the data collected up to that point will be destroyed. All data collected from participants will be destroyed within 2 years after the completion of the project.

If you have any questions or would like to receive further information about the project, please contact me at beckwijaci@myvuw.ac.nz or telephone 0210712580 , or you may contact my supervisor Professor Anne Goulding at anne.goulding@vuw.ac.nz or telephone 04 4635887.

Jacinta Beckwith 
Appendix 3: Participant Consent Form 


\section{Participant Consent Form}

Research Project Title: Measuring use of a Distance Library Service: a case study at the University of Otago

Researcher: Jacinta Beckwith, School of Information Management, Victoria University of Wellington

I have been given and have understood an explanation of this research project. I have had an opportunity to ask questions and have them answered to my satisfaction.

I understand that I may withdraw myself (or any information I have provided) from this project, without having to give reasons, by e-mailing beckwijaci@myvuw.ac.nz by December 31, 2013.

I understand that any information I provide will be kept confidential to the researcher and their supervisor, the published results will not use my name, and that no opinions will be attributed to me in any way that will identify me.

I understand that the data I provide will not be used for any other purpose or released to others.

I understand that information gathered during the interview will be erased within 2 years after the conclusion of the project.

I understand that I will be provided with a link to the electronic copy of the completed research report when it is deposited in the Victoria University of Wellington Research Archive.

Signed:

Name of participant:

Date: 
Appendix 4: Interview Schedule 


\section{Interview Schedule}

Research Project Title: Measuring use of a Distance Library Service: a case study at the University of Otago

Researcher: Jacinta Beckwith, School of Information Management, Victoria University of Wellington

As part of my INFO 580 Research project I will conduct a series of about 5 interviews with University of Otago Library staff who were part of the University of Otago Distance/Remote Library Service between 2007 and 2012.

Each interview should take no longer than 20-30 minutes and will be held on-campus in a Library seminar room.

Each interview will be structured around 5 parts:

1. Briefing section: outline of research project, purpose of interview, why participant was chosen as interviewee, participant's rights in the research

2. Discussion of participant's role within the Distance/Remote Library Service: when they were part of the service, what tasks they performed, whether they were involved with recording statistics

3. Sharing of initial findings of data analysis: summary of use (request types) and users (location, subject and level of study) statistics, expected results vs actual results, discussion of changes over time and potential causes of change, response or thoughts from participant

4. Clarification from participant of terms used for recording statistics of the Distance Library Service

5. Opportunity for questions and answers, brief summary of interview and thank participant for taking part 
Wordcount: 10,867

(excluding Disclaimer, Table of Contents, References and Appendices) 